Revista lus et Praxis, Año 24, No 2, 2018, pp. 341 - 392

ISSN 0717 - 2877

Universidad de Talca - Facultad de Ciencias Jurídicas y Sociales

Algunas consideraciones sobre el precario y la naturaleza jurídica del precarista

Arturo Selman Nahum

Trabajo recibido el 6 de febrero y aprobado el 13 de noviembre de 2017

\title{
Algunas consideraciones sobre el precario y la naturaleza jurídica del precarista
}

\section{SOME THOUGHTS OF PRECARIOUS AND THE LEGAL STATUS OF THE SQUATTER}

\author{
Arturo Selman Nahum*
}

\begin{abstract}
RESUMEN
La acción de precario, regulada en el inciso $2^{\circ}$ del artículo 2195 del Código Civil, hace décadas que viene utilizándose de forma sistemática en nuestros tribunales de justicia en contra de aquellos individuos que detentan una cosa ajena, por ignorancia o mera tolerancia del dueño. Debido a su escueta regulación normativa, ha sido la doctrina, y especialmente la jurisprudencia la encargada de establecer sus principales objetivos, límites y requisitos. Pese a lo anterior, y en razón de la interpretación que impera hoy en día en nuestros tribunales de justicia respecto del sentido o alcance del inciso $2^{\circ}$ del artículo 2195 del Código Civil, resulta interesante analizar la naturaleza jurídica del precario y el precarista bajo dicha interpretación, a efectos de determinar si este último es un mero tenedor en los términos del artículo 714 del Código Civil, o una figura distinta que se aleja de la denominada trilogía jurídica que reconoce nuestro Código Civil.
\end{abstract}

\section{ABSTRACT}

The action of precarious regulated in paragraph 2 of article 2195 of the Civil Code, for decades it has been used systematically in our courts of justice against those individuals who hold an alien thing, through ignorance or mere tolerance of the owner. Due to its bare legal regulation has been the doctrine and jurisprudence especially responsible for establishing its main objectives, limits and requirements. Despite this, and because of the interpretation that prevails today in our courts regarding the meaning or scope of paragraph 2 of article 2195 of the Civil Code, it is interesting to analyze the legal nature of precarious and squatter under this interpretation, in order to determine whether the latter is a mere holder under the terms of article 714 of the Civil Code, or different figure that departs from the so-called legal trilogy recognizes our Civil Code.

\section{Palabras Clave}

Precario, precarista, mero tenedor

KEY WORDS

Precarious, squatter, mere holder

* Licenciado en Ciencias Jurídicas y Sociales, Universidad Diego Portales. Abogado. Magíster en Tributación, Universidad de Chile. Asociado Senior en Philippi Prietocarrizosa Ferrero DU \& Uría. Dirección postal: Av. El Golf 40, Piso 20, Las Condes, Santiago de Chile. Correo electrónico: HYPERLINK "mailto:arturo.selman@gmail.com" \t "_blank" arturo.selman@gmail.com. 


\section{Introducción}

La acción de precario a lo largo de los últimos años ha sido objeto de una abundante creación jurisprudencial, siendo hoy en día, una de las pocas materias en que se puede afirmar con seguridad que la jurisprudencia dispone, sin lugar a dudas, los principales ejes de su funcionamiento. Es importante tener presente que dicha acción nace como defensa a las múltiples falencias que presenta nuestro sistema de protección al dominio, en que la acción reivindicatoria y las demás acciones que contempla nuestro ordenamiento jurídico muchas veces resultan ineficaces ${ }^{1}$ a la hora de recuperar un bien corporal que se encuentra fuera de la tenencia material de su legítimo dueño.

Debido a su escasa regulación normativa (inciso $2^{\circ}$ del art. 2195 CC), ha sido la doctrina, y especialmente la jurisprudencia, la llamada a solucionar las múltiples interrogantes que se han planteado a su respecto, encontrándose hoy en día reglada casi en su totalidad, existiendo unanimidad en la mayoría de los temas que la convocan, con la sola excepción de aquellos casos en que el sujeto pasivo de la acción se defiende exhibiendo un título que lo habilita a utilizar la cosa emanado de un tercero distinto al dueño, en cuyo caso aún se discute si dicho título es oponible al propietario que demanda la acción de precario ${ }^{2}$.

Debido a la importancia práctica que juega la acción de precario en nuestro ordenamiento jurídico, no es de extrañar que la doctrina y la jurisprudencia se hayan abocado preferentemente a su estudio como acción, dejando de lado la determinación -en específico- de la naturaleza jurídica del precarista ${ }^{3}$. En efecto, aún existen dudas acerca de su naturaleza jurídica, y, en especial, de si esta particular situación de hecho se aleja o no de la figura del mero

\footnotetext{
${ }^{1}$ En directa relación con lo anterior y con la clara intención de fortalecer la protección al dominio, la jurisprudencia -haciéndose eco del art. 915 CC- ha creado la denominada acción contra el injusto detentador. Véase: Barrientos (2005), pp. 221-249; Peñallillo, (2006) pp. 536-537; Selman (2011), pp. 57-80; Pérez (2014), pp. 387-421; Larroucau (2015), pp. 109-160, y Tapia (2015), pp. 405-422.

2 Existen pronunciamiento en ambos sentidos. Dos fallos ejemplares pueden encontrarse en LATHROP (2011), pp. 6-8.

${ }^{3}$ Lo anterior no obsta que existan pronunciamientos sobre la naturaleza jurídica del precario (situación de hecho v/s contrato), cuestión que tampoco ha sido objeto de un análisis acabado por parte de la doctrina. Por lo demás, a primera vista podría pensarse que al fijarse la naturaleza jurídica del precario se fija también la del precarista, ejercicio que no puede efectuarse de forma automática, a raíz de la forma en que se ha interpretado por nuestros tribunales de justicia el inciso $2^{\circ}$ del art. 2195 CC. En efecto, si se califica al precario como un contrato de comodato precario o una situación de hecho asimilable a él, claramente el precarista sería un mero tenedor en los términos del art. 714 CC, en cambio, si se concibe al precario como una situación de hecho ajena al comodato precario, en razón de los supuestos que contempla el art. 714 CC para ser calificado como mero tenedor, no queda claro que el precarista sea sin más, y en cualquier hipótesis, un mero tenedor.
} 
tenedor, interrogante cuya respuesta se dificulta todavía más, en razón de la interpretación que nuestros tribunales de justicia han realizado respecto del sentido o alcance del inciso $2^{\circ}$ del art. 2195 CC.

En razón de lo anterior, a lo largo del presente trabajo, en primer lugar, se analizará sucintamente la evolución del precario en la historia y en Chile, a efectos de resaltar, a juicio del autor, el sentido o alcance del inciso $2^{\circ}$ del art. 2195 CC que más se adecua a las demás instituciones que regula nuestro Código Civil. En segundo lugar, y tomando como presupuesto la concepción que se tiene hoy en día del inciso $2^{\circ}$ del art. 2195 CC, se estudiará si el precarista puede calificar como un nuevo estado del individuo frente una cosa, si corresponde a un mero tenedor en los términos del art. 714 CC, o incluso si es posible circunscribir a su respecto dos situaciones diversas, dependiendo del animus con que detente la cosa.

Con todo, es importante aclarar que la lectura del presente trabajo, requiere alejarse por un momento de la premisa que el precarista siempre debe reconocer dominio ajeno, lo que, si bien cuenta con amplio apoyo en la doctrina, y se encuentra en armonía con el alcance de dicha institución en el Derecho romano primitivo, a lo largo de este trabajo se expondrán algunas ideas que dificultan dicha postura a todo evento en el Código Civil chileno. Asimismo, de acuerdo a la posición alternativa que se plantea en este trabajo, a propósito del verdadero sentido o alcance del inciso $2^{\circ}$ del art. 2195 CC, se logra encasillar en la denominada trilogía jurídica, ciertas situaciones de hecho que hoy en día no terminan de cuadrar en el dominio, posesión, mera tenencia y la figura del precario.

\section{El precario y su evolución en la historia}

La doctrina tradicional francesa ${ }^{4}$ señala que el precario corresponde a una expresión romana, relacionada con la institución de la clientela. La clientela por su parte, si bien tiene un origen incierto ${ }^{5}$, consistía básicamente en que un hombre libre se situaba bajo "la protección de un ciudadano (patrono) o de un grupo de familias (gentilidad)" ${ }^{6}$. En esta misma línea, Bonfante señala que "la institución del precarium tuvo probablemente su origen en las relaciones entre patrono y cliente" ${ }^{\prime 7}$. En términos similares, Petit señala que "El origen de este

${ }^{4}$ Colin y Capitant (1923), p. 877.

${ }^{5}$ No se tiene absoluta claridad si los clientes eran enemigos vencidos no esclavizados, proletarios o inmigrantes que solicitaban protección.

${ }^{6}$ Castillejo (2004), p. 56.

7 Bonfante (1944), p. 91. 
uso es oscuro. Se ha conjeturado que se había establecido a propósito de la explotación del ager publicus. Los patricios hacían a sus clientes concesiones esencialmente revocables" ${ }^{\prime \prime}$.

Si bien el precario tuvo su máxima expresión en el Derecho romano, de allí que se singularice como una institución romana, existe conceso que "su origen no fue algo exclusivo del Derecho de Roma" ${ }^{\prime \prime}$. En efecto, el precarium tiene sus orígenes en la clientela, institución prerromana "que se refiere no a la civitas sino a los núcleos que precedieron a ésta, es decir, a las gentes" ${ }^{\prime \prime 10}$, y ello por cuanto "la clientela es mencionada no sólo con relación a las razas propiamente itálicas, latinas, sabinas y sabélicas, si que también con respecto a los etruscos, helenos y celtas"11.

Clarificado lo anterior, y pese a la dificultad de determinar los orígenes específicos del precario, es posible detectar tres elementos centrales que conforman esta institución en su concepción más antigua, a saber: la concesión del ager publicus (propiedad pública), dentro del contexto de la clientela, bajo la organización social de la gens (organización social propia de la antigua Roma ${ }^{12}$ ). De estos elementos, cobra especial relevancia la figura de la clientela, que como se dijo comprendía la sujeción de un hombre libre bajo la protección de un patrono. Así el cliente "presta obediencia y debe reverencia al patrono, está obligado al servicio militar en favor de la gens ${ }^{\prime \prime 13}$, y el patrono como contrapartida, "debe al cliente protección, apoyo, consejo y principalmente le asiste en los juicios"14. Esta relación se desenvuelve dentro del seno de la gens, en cuya virtud el cliente "cultiva las tierras del patrono, y éste le asigna, por lo general, parcelas laborales, asignación que puede revocar a su

\footnotetext{
8 Petit (2007) p. 426.

9 Moreno (1951), p. 24.

10 Bonfante (1944), p. 89.

11 Bonfante (1944), p. 89.

12 Existen dos doctrinas referidas al origen de la gens, la primera, sustentada en un texto de Dionisio de Halicarnaso que se refiere a la división de las curias en diez decenas, mientras que la segunda, la asimila a las familias descendientes de un tronco común. Bonfante considera que la gens es "el núcleo político precedente de la civitas, una aglomeración de familias que, según las circunstancias o la fortuna de una determinada gens, puede constituir con los propios sujetos y esclavos una gran casa o burgo, un municipio". Véase Bonfante (1944), pp. 85-86. En este sentido, para Bonfante, la gens pasa a tener clases sociales, en que estarán los gentiles de pleno derecho y los miembros dependientes o clientes, situación última que dice relación con el precario, en el entendido que ésta se desarrolló bajo la estructura de la gens.

13 Bonfante (1944), p. 91.

14 Bonfante (1944), p. 91.
} 


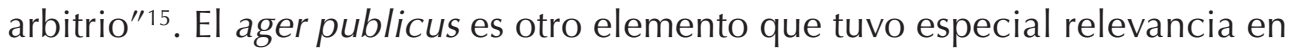
la figura del precario, toda vez que este último se desarrolló principalmente en tierras del Estado ${ }^{16}$, especialmente en la economía más antigua de Roma, en que se restó importancia al ager privatus (propiedad privada). Bajo el sistema antes indicado, el precarium surgió como mecanismo por excelencia en el uso de cosa ajena ${ }^{17}$.

En resumidas cuentas, y bajo el tratamiento del Derecho romano en su concepción más antigua, el precario dans concedía gratuitamente la posesión de tierras al precario accipiens, concesión que era esencialmente revocable, y que contemplaba como mecanismo de resguardo el interdicto quod precario ${ }^{18}$. Para Guzmán, es discutible que dicho interdicto tenga el carácter de posesorio, por cuanto el precarista podía defenderse alegando dominio u otra calidad que justifique la tenencia, lo que es impropio de los interdictos posesorios ${ }^{19}$.

De conformidad a las características particulares antes expuestas, y producto de cierta desnaturalización de las mismas, el precario con el tiempo devino en un contrato innominado ${ }^{20}$, postura que para algunos cobró cierta relevancia

15 Bonfante (1944), p. 91.

${ }^{16}$ Las tierras públicas eran poseídas por los patronos, previo pago de un censo, y éstas a su vez, podían ser entregadas gratuitamente a los clientes. Como puede apreciarse, el precario en sus orígenes suponía la concesión de alguien que no era dueño de las tierras que entregaba en posesión precaria.

17 Moreno (1951), pp. 26-27.

${ }^{18}$ Véanse los comentarios del Jurisconsulto Ulpiano respecto de este interdicto especial: (i) D. 43, 26, 2 pr.: "Dice el Pretor: «Le restituirás á uno lo que de él tienes en precario, ó hiciste con dolo malo que dejaras de tenerlo, y por cuya cosa se reclama". (ii) D. 43, 26, 2,2: "Y contiene en si equidad natural; porque le compete al que quiere revocar el precario. Porque es equitativo por naturaleza que uno use de mi liberalidad en tanto que yo quiera, y que yo pueda revocarla cuando hubiere cambiado de voluntad. Y así, cuando se rogó alguna cosa en precario, podemos usar no solamente de este interdicto, sino también de la acción de las palabras prescritas (praescriptis verbis actione), que nace de la buena fe". Asimismo, Ilama la atención el carácter perpetuo que los autores han atribuido a este interdicto, con base en lo señalado por Ulpiano en el Digesto: "Escribe Labeon, que este interdicto compete también después del año, y este derecho observamos; porque concediéndose algunas veces el precario por largo tiempo, es absurdo decir que el interdicto no tiene lugar después del año" (véase: D. 43, 26, 8,7), circunstancia que separaría este interdicto de los estrictamente posesorios.

19 GuZMÁn (1996), p. 521.

20 "En fin, en el último estado del Derecho, el precario ocupó un puesto entre los contratos innominados, y el concedente tiene, para hacerse restituir la cosa, la acción praescriptis verbis". Véase: PETIT (2007) p. 426. En este mismo sentido Morineau e Iglesias, al tratar el precario, lo circunscriben dentro de la categoría de contratos innominados, que, en sus palabras "aparecieron con el reconocimiento de determinadas convenciones que no figuraban en la lista tradicional de los contratos. Son figuras que se apartan de los contratos típicos del derecho clásico (...)". Véase: Morineau y IGLESIAS (1998), pp. 192-193. De igual forma lo desarrolla Arguello, quien señaló sobre el particular que "la convención por la que una persona concedía gratuitamente a otra el uso de una cosa corporal o incorporal, propia o ajena, que se obligaba a restituir o a cesar en el uso de ella a petición del concedente, configuró el contrato 
en el Derecho romano clásico ${ }^{21}$ y mayor fuerza en el Derecho postclásico y Justiniano ${ }^{22}$.

Es más, aunque el precario en sus inicios más antiguos era una situación de hecho que no obligaba jurídicamente al precario dans, lo cierto es que ello se desarrolló en un contexto en que los clientes debían "un margen de sujeción y servicio que justificase la concesión sin vinculación por el concedente $(\ldots)^{\prime 23}$. En otras palabras, el precario desde sus inicios en Roma -O incluso en el período prerromano-, aunque se aleja de la figura contractual constituyendo un tipo especial de posesión ${ }^{24}$

innominado de precario". Con todo, el referido autor aclara que esta institución entró en la categoría de contratos innominados en el Derecho Justiniano. Véase: ArGüEllo (1998), p. 336. Samper por su parte, al tratar los contratos innominados, también incorpora al precario en su listado, pero señala a dicho respecto que "(...) en el derecho clásico no es contrato, sino un vicio de la posesión, simple situación de tenencia, ajena al campo de las obligaciones, y protegida por interdictos posesorios". Véase: SAMPER (2007), p. 342.

${ }^{21}$ Si bien durante este período, al igual que en el Derecho Romano primitivo y el Derecho Romano pretorio, se continúa sosteniendo por la mayoría de los autores (MORENO MOCHOL, SoHM y BONFANTE) que el precario mantiene sus características más antiguas, la definición de Ulpiano comprendida en el Digesto siembra algunas dudas al definirlo con un aire convencional: "Es precario lo que al que lo pide con ruegos se le concede para que lo use en tanto que lo consiente el que se lo concedió" (véase: D. 43, 26, 1 pr.). En apoyo a la postura mayoritaria, Petit señala que, pese a que "ciertos textos otorgan la acción praescriptis verbis al precarista desde la época clásica [...] parece cierto que estos textos han sido interpolados, ya en el bajo imperio (Cf. Paulo, S., V. 6., §10) ya bajo Justiniano; y que el precario no ha sido tratado como contrato innominado por los jurisconsultos clásicos". Véase: Petit (2007) p. 426. Con todo, ya en el período postclásico y Justiniano, no existen mayores disidencias en cuanto a la destaturalizacion del precario, y su paso a una figura innominada contractual.

22 Época en la cual se concede al que dio una cosa en precario, ya no sólo el interdicto de precario, sino además la condictio incerti (véase: D. 43, 26, 19,2) y la acción prescriptis verbis (véase: D. 43, 26, $2,2)$, acción que se utilizó por regla general para dar fuerza de contrato a las convenciones que carecían de acción, y que, complementando la condictio incerti que únicamente buscaba volver las cosas a su estado primitivo, imponía además la ejecución de lo convenido. Véase: Moreno (1951), p. 214.

23 Moreno (1951), p. 36.

${ }^{24}$ Es importante clarificar que en el Derecho romano se distinguió entre la posesión natural, símil a la mera tenencia, que no encuentra protección jurídica a través de los interdictos, y la posesión civil, que es la que ejerce como dueño -aunque no lo fuera-, y faculta la adquisición del dominio. Con todo, también se protegió la posesión ad interdicta, entendida como la que se ejerce sobre una cosa que se encuentra protegida por los interdictos (distinta de la posesión civil y natural), cual sería el caso del precarista, el que, para efectos prácticos, se consideró como un verdadero poseedor, el cual podía defenderse en contra de la perturbación de terceros mediante el interdicto Uti possidetis, teniendo como único límite ejercer este interdicto contra el precario dans. En virtud de esta protección especial, se generaba una situación bastante peculiar por cuanto no solo poseía el precario dans, sino también el precarista. De allí que algunos Jurisconsultos como Trebacio, sobre la base de esta peculiaridad, haya señalado "que uno podía poseer justamente, y otro injustamente; pero que dos no podían poseer injustamente ó justamente" (D. 41, 2, 3,5). Respecto del reconocimiento del precario como posesión 
o tenencia ${ }^{25}$, se caracterizó en que tanto el patrono como el cliente efectuaban -en mayor o menor medida-concesiones recíprocas, el primero de protección y el segundo de obediencia y apoyo militar, ello sin perder de vista que el patrono disponía arbitrariamente de la voluntad revocatoria de la concesión.

En estos términos, si bien existe conceso entre los autores en que el precario en su período primitivo y en el derecho pretorio -y el período clásico para la mayoría de la doctrina- no constituía un contrato, era una figura compleja ${ }^{26}$, que por sus características peculiares requirió la creación de una figura jurídica especial de protección, el interdicto quod precario, diverso al interdicto para recuperar la posesión, lo que denota la importancia que jugó esta institución en el Derecho romano.

En la época medieval y el Derecho moderno, el precario continuó la tendencia del Derecho postclásico y Justiniano, asimilando esta institución a una figura contractual, refiriéndose a ella derechamente como una posesión a nombre de otro, además de confluirse en ciertos aspectos con el contrato de arrendamiento, tal como refleja la Ley XII y XIII del Fuero Juzgo en su versión castellana, en que al regularse la posesión precaria (más que el precario), en su epígrafe señala "E de las tierras arrendadas" 27 . En la época medieval propiamente tal, producto de la influencia del Derecho germánico y especialmente del Derecho canónico, se

en el Derecho romano, véanse los siguientes pasajes del Digesto: (i) D. 43, 26, 4,1: "Mas debemos tener presente que el que tiene en precario también posee"; (ii) D. 43, 26, 15,4: "No es dudoso que adquiere la posesión el que hubiere rogado en precario que le sea licito poseer. Se dudó si también poseerá aquel á quien se le hubiera rogado; mas está determinado, que el esclavo, que hubiese sido dado en precario, esté en poder de uno y de otro, en poder del que lo hubiese rogado, porque lo posee corporalmente, y en poder del dueño, porque no se separé de la posesión con el ánimo"; (iii) D. 43, 26, 16: "Si yo hubiere adoptado al que hubiere rogado en precario, yo también poseeré en precario". (iv) D. 43, 26, 17: "El que en precario posee un fundo puede usar del interdicto Uti possidetis contra todos, excepto contra aquel a quien le rogó". Esta peculiar situación es reconocida por Guzmán, quien señala que el precarista era considerado un poseedor pretorio con valor relativo, por cuanto frente a terceros se encontraba protegido con los interdictos uti possidetis y utrubi, mientras que frente al precario dans, su tenencia era considerada una possessio iniusta o vitiosa. Véase: Guzmán (1996), p. 777. 25 "De esta manera el precarium aparece como el último grado de tenencia de una cosa, el más inestable de todos, después de la posesión civil del dueño, de la del no-dueño y de la posesión natural". Véase: GUZMÁN (1996), p. 779.

${ }^{26}$ Con todo, y sin perjuicio de las características singularísimas de esta institución, "en principio nadie ha discutido y todos los tratadistas están de acuerdo en que al precarista se le reconoció como verdadero poseedor, dado que la expresión de los textos no puede ser más unánime y clara". Véase: MOREno (1951) p. 124. En efecto, en sus orígenes el precario se asimilaba a la posesión, y por muchos autores es tratada como un vicio de la posesión.

27 Moreno (1951), pp. 238-239. Con todo, existen otros cuerpos legales de la época, como las Partidas, en que primó el sistema posesorio romano por sobre el germano, lo que en demuestra la persistencia histórica del Derecho romano. 
manifestó una nueva institución, denominada "precaria", que, si bien mantiene algunos aspectos propios del precario en su concepción clásica, incorpora ciertas restricciones -temporales o por toda la vida-, respecto a la posibilidad de hacer cesar dicha concesión ${ }^{28}$. En efecto, en "el Derecho medieval, en ocasiones los particulares donaban bienes a favor de la Iglesia, y ésta devolvía acto seguido a los donantes los bienes recibidos, acrecentados casi siempre con otros de su patrimonio, mediante el pago de cierto canon estipulado al efecto, o la prestación de ciertos servicios a condición de que, expirado el término convenido, volviesen los bienes al poder y dominio de la Iglesia. El conjunto de estas relaciones es lo que se denominaba precaria" 29 . En los tiempos modernos, por su parte, y hasta antes de la codificación, el precario se mantuvo en términos similares a los descritos en la época medieval, y aunque el estudio de la posesión incorpora elementos canónicos y germánicos, el Derecho romano sigue siendo la piedra angular, con las variantes propias de la época. Ya en la fase de la codificación, se termina de consolidar la lejanía al precarium en su concepción originaria del Derecho romano más antiguo, relegando esta institución a una especie o tipo de contrato innominado ${ }^{30}$.

A propósito de evolución del precario en Derecho romano, Barrientos señala que "(...) Tal situación cambió cuando el pretor prometió en su edicto el interdicto Quod precario, que permitía al precario dans exigir la restitución de la cosa al precarista que no la restituía cuando le era exigida (Digesto, $43,26,2$,pr.), concesión esta, que Pomponio explicaba, porque había suma equidad en que se usara de lo nuestro sólo en la medida en que quisiéramos (Digesto, 43,26,15,pr.). Pero, además, en época justinianea se consolidó una tendencia, que debe remontarse a época posclásica, según la cual se daba en el caso del precario una acción (actio praescriptis verbis), de donde resultaba atraído a la categoría, tampoco clásica, de "contratos innominados"

Ejemplo de esta evolución -y desnaturalización- se manifiesta en Francia. Así, por ejemplo, Planiol y Ripert señalaron que: "la posesión en precario nunca es un hecho irregular, contrario al derecho, mientras que la verdadera posesión lo es muy a menudo, por ejemplo, en caso de robo o usurpación. Todas las personas que poseen una cosa en precariamente la detentan en virtud de un título regular; han celebrado un contrato con el propietario o bien están encargadas por la ley o la justicia de una misión especial; y, si la cosa ajena

28 Moreno (1951), p. 228.

29 CANO (1999), p. 54.

30 Moreno (1951), pp. 249-252. Misma postura defiende Cano (1999) en las conclusiones de su obra.

31 Barrientos (2016), p. 933. Énfasis agregado. 
se encuentra en su poder, es por la ejecución de este contrato o de esta misión $(\ldots)^{\prime \prime 32}$. En efecto, en las pocas disposiciones del Código Civil francés en que se alude directamente a la posesión precaria (artículos $2266^{33}$ y 226934), ésta se asimila a la que detenta el arrendatario, el depositario y el usufructuario, situaciones de mera tenencia que requieren de la celebración de un contrato con el dueño de la cosa.

En términos similares, los Códigos Civiles de España ${ }^{35}$, Italia ${ }^{36}$, Portugal $^{37}$, Alemania ${ }^{38}$, México ${ }^{39}$ y Argentina ${ }^{40}$, incorporan o adecuan la figura del precario en el contrato de comodato, específicamente en aquellas hipótesis de indeterminación en cuanto al tiempo y uso de la cosa (comodato precario).

32 Planiol y Ripert (1997), pp. 395-396. Énfasis agregado.

${ }^{33}$ Artículo 2266 del Código Civil de Francia: "Quienes poseen por otro no prescriben nunca durante el tiempo que sea. Así, el arrendatario, el depositario, el usufructuario y todos los demás que poseyeren precariamente la cosa o el derecho del propietario no pueden prescribirla" (énfasis agregado) (traducción libre) [incorpora modificación introducida por la Ley № 2008-561 de 17 de junio de 2008 - art. 2].

${ }^{34}$ Artículo 2269 del Código Civil de Francia: "Quienes hubieren transmitido la cosa o el derecho a los arrendatarios, depositarios y otros poseedores precarios por un título traslativo de propiedad, pueden prescribirla" (énfasis agregado) (traducción libre) [incorpora modificación introducida por la Ley № 2008-561 de 17 de junio de 2008 - art. 2].

${ }^{35}$ Artículo 1750 del Código Civil de España: "Si no se pactó la duración del comodato ni el uso a que había de destinarse la cosa prestada, y éste no resulta determinado por la costumbre de la tierra, puede el comodante reclamarla a su voluntad. En caso de duda, incumbe la prueba al comodatario".

${ }^{36}$ Artículo 1810 del Código Civil de Italia: "Si no se acordó un plazo o el uso de la cosa que se iba a utilizar, el comodatario estará obligado a devolverla tan pronto como el comodante lo solicite" (traducción libre).

37 Artículo 1137 del Código Civil de Portugal: "Si los contratantes no acordaron un plazo cierto para la restitución de la cosa, pero ésta fue prestada para un uso determinado, el comodatario deberá restituirla al comodante tan pronto como el uso termine, sin cuestionamiento" (traducción libre).

$38 \S 604,3^{\circ}$ del Código Civil de Alemania (BGB): "Si no se ha especificado la duración del préstamo, ni puede inferirse del propósito del préstamo, el comodante puede exigir la cosa de vuelta en cualquier momento" (traducción libre).

${ }^{39}$ Artículo 2511 del Código Civil Federal de México: "Si no se ha determinado el uso o el plazo del préstamo, el comodante podrá exigir la cosa cuando le pareciere. en este caso, la prueba de haber convenido uso o plazo, incumbe al comodatario".

${ }^{40}$ Artículo 2285 del antiguo Código Civil de Argentina: "Si el préstamo fuese precario, es decir si no se pacta la duración del comodato ni el uso de la cosa, y éste no resulta determinado por la costumbre del pueblo, puede el comodante pedir la restitución de la cosa cuando quisiere. En caso de duda, incumbe la prueba al comodatario" (se hace presente al lector que este artículo pertenece al antiguo Código Civil de 1869, y no al Código Civil y Comercial de la Nación Argentina en actual vigor). 
Los Códigos Civiles de Chile, Colombia ${ }^{41}$ y Ecuador ${ }^{42}$ innovan respecto de la estructura utilizada en los Códigos citados precedentemente, ya que si bien los tres regulan aquellos casos en que no se presta la cosa para un servicio particular ni se fija tiempo para su restitución, a renglón seguido señalan que constituye también precario la tenencia de una cosa ajena, sin previo contrato y por ignorancia o mera tolerancia del dueño. En Chile, esta institución se encuentra contemplada en el inciso $2^{\circ}$ del art. 2195 CC, cuyo texto del artículo en su integridad, es del siguiente tenor:

"Se entiende precario cuando no se presta la cosa para un servicio particular ni se fija tiempo para su restitución.

Constituye también precario la tenencia de una cosa ajena, sin previo contrato y por ignorancia o mera tolerancia del dueño".

En razón de la innovación introducida por los Códigos Civiles de Chile, Colombia y Ecuador, y en lo atingente a Chile, la única forma de determinar el real sentido o alcance de la disposición contenida en el inciso $2^{\circ}$ del art. 2195 CC es acudir a las notas explicativas del Proyecto Inédito del Código Civil chileno, y al análisis interpretativo del texto de la ley, lo que nos permitirá, por una parte, conocer las principales consideraciones que tuvo a la vista Bello para la redacción de este controvertido inciso, y, por la otra, intentar dilucidar el real sentido o alcance de esta disposición.

\section{El origen normativo del precario en el Código Civil chileno y su alcance a la luz de su correcta interpretación}

El Proyecto Inédito del Código Civil, específicamente el art. 2337 (actual art. 2195 CC) dispuso a su respecto lo siguiente: "C. Báv. libro IV, c. 2, art. $11^{\prime \prime}$. La nota de Bello no hace más que referirse al Código bávaro, que en lo pertinente señalaba: “(...) Respecto al préstamo de tolerancia, o sea, a título precario (precarium), se observarán las mismas reglas (las del préstamo propiamente dicho o comodato), excepto en cuanto el prestador puede pedir la cosa prestada cuando le acomode" ${ }^{\prime 43}$.

\footnotetext{
${ }^{41}$ Artículo 2220 del Código Civil de Colombia: "Se entiende precario cuando no se presta la cosa para un servicio particular, ni se fija tiempo para su restitución.

Constituye también precaria $<\mathrm{sic}>$ la tenencia de una cosa ajena, sin previo contrato y por ignorancia o mera tolerancia del dueño".

${ }^{42}$ Artículo 2098 del Código Civil de Ecuador: "Se entiende precario cuando no se presta la cosa para un servicio particular, ni se fija tiempo para su restitución.

También lo constituye precario la tenencia de una cosa ajena, sin previo contrato y por ignorancia o mera tolerancia del dueño".

${ }^{43}$ Figueroa (1998), p. 22.
} 
A primera vista se denota que la fuente utilizada por Bello no hace más que referirse a la figura contractual del comodato precario. Ahora bien, pareciera ser que esta nota explicativa únicamente circunscribe a su respecto el inciso $1^{\circ}$ del art. $2195 \mathrm{CC}^{44}$, más no su inciso $2^{\circ}$. Esta postura ha sido planteada por Domínguez, quien sostuvo sobre la referida nota explicativa lo siguiente: "(...) No siempre se usa el argumento histórico y las notas de Bello con la exactitud requerida. En efecto, es verdad que una nota de Bello al Proyecto Inédito dice C. Báv. libro IV, c. 2, art. 11, pero el Código bávaro no hace referencia a la situación de hecho prevista en el inc. $2^{\circ}$ de nuestro art. $2195(\ldots)^{\prime \prime 45}$. Más adelante agrega que: "Esta hipótesis es de antigua data y era conocida por el Derecho Romano: "Precarium est, quod précibus petendi utendum concéditur tamdiu, quamdiu is qui concessit pátitur" (Ulpiano, Dig. 48.26.1). Así, lo que distingue al comodatum propiamente tal del precarium es la posibilidad del prestador de pedir la cosa en cualquier tiempo"46. Para Domínguez, la situación descrita en el inciso $2^{\circ}$ del art. 2195 CC, si bien tiene sus orígenes en el Derecho romano, e incluso se asemeja en su regulación al Código prusiano (en razón de que dicho Código circunscribe la regulación del precario dentro del contexto de un contrato), termina concluyendo que su creación como tal es propia del ingenio de Bello, y, por lo mismo, su sentido o alcance debe interpretarse de acuerdo con el texto de la ley ${ }^{47}$.

En este sentido, Domínguez dispuso: "Mas es lo cierto que esa situación de hecho, cuya naturaleza es discutible, aparece asimilada en el art. 2195 inc. $2^{\circ}$ a la situación contractual del contrato de comodato precario, desde que el inc. $1^{\circ}$ señala que "Se entiende precario cuando no se presta la cosa para un servicio particular ni se fija tiempo para su restitución". Este contrato de precario, cuyos orígenes romanos hemos referido, es un acuerdo de voluntades y que se separa del comodato porque éste tiene un plazo para la restitución, sea fijado en la convención, sea determinado por el uso de la cosa. Pero si esa determinación expresa o tácita no existe, el contrato es de comodato precario. El inciso 2 agrega que "Constituye también precario" la situación de hecho a la que se refiere, es decir, también se rige por las mismas reglas y, por lo mismo, se asimila a una situación contractual. No deberá olvidarse que siendo Bello un eximio gramático y conocedor de nuestro idioma castellano, no pudo sino

\footnotetext{
${ }^{44}$ Sin perjuicio de lo anterior, y suponiendo que la nota explicativa se refiera al art. 2195 CC en su integridad, significaría que Bello entendió la situación contenida en el inciso $2^{\circ}$ como un tipo o especie de comodato precario.

45 Domínguez (1995), p. 194.

46 Domínguez (1995), p. 194.

47 Domínguez (1995), pp. 194-195.
} 
tener presente que el uso del adverbio "también" implicaba esa asimilación, pues "se usa para afirmar la igualdad, semejanza, conformidad o relación de una cosa con otra ya nombrada", concepto que aunque es el del actual Diccionario de la Real Academia no podía sino ser el mismo en 1855"48.

Se comparte la postura planteada por Domínguez, toda vez que el adverbio "también" sin lugar a dudas entrelaza el inciso $2^{\circ}$ del art. 2195 CC con su inciso $1^{\circ}, y$, por lo mismo, es dable sostener que lo asimila a la figura contractual del comodato precario. Francamente, resulta difícil creer que Bello, con la agudeza e ingenio que lo caracterizaba, haya pretendido regular en un solo inciso la institución del precario en los términos concebidos en el Derecho romano antiguo. En razón de su sucinta regulación y a su ubicación en el Código Civil (Libro IV, Título XXX del comodato o préstamo de uso), resulta razonable sostener que esta situación de hecho descrita en el inciso $2^{\circ}$ del art. 2195 CC se asimila a la figura contractual del comodato precario, con las variantes evidentes que la propia norma contempla.

En esta misma línea, Atria señala que "(...) el uso de la palabra "también" en esa regla: "constituye también [es decir, también comodato] precario la tenencia de una cosa ajena, sin previo contrato, y por ignorancia o mera tolerancia del dueño". Pero una atenta lectura de los dos artículos en cuestión muestra que no hay contradicción: en virtud del contrato de comodato el comodante debe respetar el uso que el comodatario hace de su cosa, salvo que se reserve la facultad de pedir la restitución en cualquier tiempo. En este último caso el contrato "toma el título de precario" (art. 2194 cc). El artículo 2195 contiene dos reglas: una (la del inciso primero) que pretende interpretar la voluntad de las partes y otra que califica como precario lo que de acuerdo a su naturaleza no lo es (inciso segundo)" 49 .

Una opinión similar sostuvo Claro Solar, quien, al referirse a la institución del precario dispuso lo siguiente: "El precarium no es desconocido en nuestro Código; pero no en el sentido en que el Código francés lo aplica a la posesión. "El comodato, dice el art. 2194, toma el título de precario si el comodante se reserva la facultad de pedir la restitución de la cosa en cualquier tiempo". El art. 2195 añade: "Se entiende precario cuando no se presta la cosa para un servicio particular, ni se fija tiempo para su restitución. Constituye también precario la tenencia de una cosa ajena, sin previo contrato y por ignorancia o mera tolerancia del dueño". Es la misma institución romana, pero, simplemente, una forma especial del contrato de comodato o préstamo de uso, contrato de beneficencia

48 Domínguez (2005), pp. 343-344. Énfasis agregado.

${ }^{49}$ ATRIA (2005), pp. 30-31. 
como el precarium romano, contrato real, porque "no se perfecciona sino por la tradición de la cosa", según el art. 2174, es decir, por la entrega de la cosa, pues "el comodante conserva sobre la cosa prestada todos los derechos que antes tenía, pero no su ejercicio en cuanto fuere incompatible con el uso concedido al comodatario" (art. 2176), uso que en el precario se refiere a todos los servicios de que la cosa es susceptible. Mas, obligado el comodatario a restituir la misma cosa prestada, es, mientras dura el comodato, simple tenedor de ella y no adquiere la posesión en conformidad al art. 714 que considera mero tenedor al que tiene una cosa reconociendo dominio ajeno (... $)^{\prime \prime 50}$.

Es del caso destacar que esta interpretación es compartida por el jurista español Moreno Mocholi, quien en su obra "El Precario", al referirse al derecho comparado, en particular a la regulación del precario en Chile, señala: “(...) Si por el lugar en que se trata la institución y el que en definitiva otorga al comodato, como si fuera la figura normal o principal, no llega a la solución conforme a la naturaleza estricta del precario; se aproxima bastante, al reconocer su verdadera relación que no amplía, sino al extenderlo aparentemente lo que hace es describir su propia esencia, si bien no la trate en puridad como tal, sino como un aspecto más, frente a aquél otro cual el contractual, puramente accidental y secundario" ${ }^{\prime \prime 1}$.

Es dable sostener, entonces, que el alcance que Bello quiso plasmar en el inciso $2^{\circ}$ del art. $2195 \mathrm{CC}$ es asimilable al comodato precario. En efecto, y aunque resulta evidente que el referido inciso alude a una situación fáctica especial, ello no es óbice alguno para asimilarlo a la figura contractual del comodato precario, con las consecuencias que ello supone.

Entonces, no resulta aventurado sostener que Bello nunca pretendió diferenciar, en su esencia y efectos, el contrato de comodato precario con la figura comprendida en el inciso $2^{\circ}$ del art. 2195 CC $^{52}$. Ahora bien, aquí no se pretende efectuar una crítica histórica al sentido o alcance que la jurisprudencia ha atribuido al precario, sino más bien reflejar que esta figura -como se conoce hoy

50 Claro (2013), pp. 457-458. Énfasis agregado.

51 Moreno (1951), p. 258. Énfasis agregado.

52 Un interesante contrapunto en BARRIENTOS (2016), pp. 944-945. Con todo, y resultando imposible determinar sin duda alguna cuál fue el verdadero sentido que Bello quiso otorgar a tan controversial inciso, a juicio de quien escribe, el inciso $2^{\circ}$ del art. 2195 CC debe leerse en armonía con la estructura del dominio, posesión y mera tenencia que consagra nuestro Código Civil, y por lo mismo, es aconsejable darle una lectura que no solo cuenta con argumentos de texto de peso, sino que, además, se adecua a la trilogía jurídica que consagra el Código Civil. En efecto, concebir al precario de acuerdo al Derecho romano más antiguo supone reconocerle al precarista una calidad especial en la tenencia del bien, que desconoce nuestro Código Civil, además de las protecciones propias que a dicha figura se le reconocían en el Derecho romano, no contempladas en el Código de Bello, por razones evidentes. 
en día- tiene un origen eminentemente jurisprudencial, lo que trae aparejado como consecuencia que la naturaleza jurídica del precarista difícilmente podrá circunscribirse, sin más, en alguna de las situaciones tradicionales que un individuo puede encontrarse frente a una cosa, básicamente porque la jurisprudencia se ha alejado, a juicio del autor, de su origen que lo asimilaba a un contrato.

De conformidad a lo expuesto precedentemente, es dable sostener que la interpretación que se sigue hoy en día del precario difiere a la correcta doctrina. Entonces, si para Bello el inciso $2^{\circ}$ del art. 2195 CC era asimilable a la figura contractual del comodato precario, no es de extrañar que todos aquellos individuos que no fueran dueños o poseedores de una cosa, y se encontrasen en la hipótesis planteada en dicho articulado, hayan sido relegados a la mera tenencia ${ }^{53}$. Bajo esta perspectiva, el denominado precarista estaría relegado a la figura de la mera tenencia, haciendo la salvedad de que dicha clasificación no se funda en una regla de descarte, como algunos proponen, sino más bien en su naturaleza singular asimilable a un contrato.

En del caso destacar que nuestros tribunales de justicia han interpretado el precario de una forma distinta ${ }^{54}$, motivo por el cual en el apartado siguiente se expondrá la postura predominante de la jurisprudencia de los últimos treinta años $^{55}$, y, a la luz de dicha interpretación, se mencionarán algunos problemas que dificultan la calificación del precarista como un mero tenedor a todo evento, lo que en cierta forma denota que la complejidad en la calificación de la naturaleza jurídica del precarista se justifica, en parte, por la concepción que tiene la jurisprudencia respecto de la naturaleza jurídica del precario.

En la actualidad, nadie discute que el Ilamado precarista, para ser considerado como tal, debe carecer de un título o contrato que lo habilite a ocupar la cosa. En este orden de ideas, y con el solo ánimo de adelantar la dicotomía que se genera en el actual sistema, se llega al absurdo de comprender al precarista como un mero tenedor (en los términos del inciso $1^{\circ}$ del art. $714 \mathrm{CC}$ ), pero a su vez, reconociendo que la acción de precario sólo procede en casos de ausencia de título o contrato que justifique la tenencia de la cosa, requisito característico -e indispensable para algunos autores clásicos- de la mera tenencia. Es decir,

\footnotetext{
53 En efecto, si para Bello la situación descrita en el inciso $2^{\circ}$ del art. 2195 CC era asimilable al comodato precario, todo aquel que se encontrase en la hipótesis de dicho inciso forzosamente sería un mero tenedor.

${ }^{54}$ Calificándolo como una mera situación o cuestión de hecho. En la nota al pie de página № 68 se citan un conjunto de sentencias que demuestran la posición predominante de la jurisprudencia de nuestros Tribunales Superiores de justicia a dicho respecto.

55 La que ha diferenciado tajantemente la situación que contempla el inciso $2^{\circ}$ del art. 2195 CC, respecto del contrato de comodato precario, calificándolo como una mera situación o cuestión de hecho.
} 
se asimila al mero tenedor con el precarista, olvidando que por regla general no se puede ser mero tenedor sin un título o contrato que habilite la utilización de la $\cos ^{56}$.

\section{Aproximaciones a la naturaleza jurídica del precario y el precarista}

Tal y como se adelantó en las páginas anteriores, la naturaleza jurídica del precarista es un interrogante que no ha sido objeto de mayor análisis por parte de la doctrina y la jurisprudencia ${ }^{57}$, lo que no obsta que existan ciertos autores que lo encasillan en la figura de la mera tenencia ${ }^{58}$.

Por su parte, la determinación de la naturaleza jurídica del precario tampoco es una cuestión resuelta en la doctrina, aunque existe una postura mayoritaria de parte de la jurisprudencia. Así, la Corte Suprema desde antigua data ha señalado que "[E]l comodato o préstamo de uso es un contrato, esto es, un acuerdo de voluntades que liga jurídicamente a las partes, en la forma establecida en el artículo 1438 del Código Civil. En cambio, lo que para la ley constituye también precario, conforme al artículo 2195 inciso $2^{\circ}$ del mismo Código, es como esta Corte lo ha declarado una simple situación de hecho, con absoluta ausencia de todo vínculo jurídico entre dueño y tenedor de la cosa, una tenencia meramente sufrida, permitida, tolerancia o ignorada, sin fundamento, apoyo o título jurídicamente relevante. (Sentencia de 31 de julio de 1986, Gaceta Jurídica № 73, página 63)" 59 .

\footnotetext{
${ }^{56} \mathrm{Si}$ bien el autor postula la posibilidad de ser mero tenedor sin un título o contrato, ello podrá ser posible únicamente en los casos en que el detentador de la cosa reconozca dominio ajeno (inciso $2^{\circ}$ del art. 714 CC). La doctrina tradicional, por el contrario, asimila la mera tenencia a un título no traslaticio de dominio cuyo fundamento sea un derecho real o personal. Bajo esa perspectiva, ¿cómo podría ser el precarista un mero tenedor?

${ }^{57}$ Con todo, existen contadas sentencias que hacen alusión al precarista, y que se mencionan en la nota al pie de página № 100 .

${ }^{58}$ BARCiA (2010), p. 59. En términos similares se pronuncia BARRIENTOS (2005) p. 230, según se expondrá en el capítulo 5.- del presente trabajo. Como se ha venido señalando a lo largo de este trabajo, se comparte que el precarista será un mero tenedor a todo evento, si se asimila la situación del inciso $2^{\circ}$ del art. 2195 CC a la figura del comodato precario. En caso contrario, sólo será mero tenedor si reconoce dominio ajeno, ya que, si ello no ocurre, se genera una figura que se aleja del dominio, posesión y mera tenencia. Incluso, en la hipótesis de ocupación de un inmueble sin reconocimiento de dominio ajeno, y además con ánimo de señor o dueño, el precarista será más bien un detentador con rasgos posesorios o eventualmente un poseedor irregular (ver nota al pie de página $\mathrm{N}^{\circ} 77$ ), dependiendo del valor que se otorgue a la inscripción registral y de la doctrina que se siga respecto a los requisitos que se deben cumplir para adquirir la posesión irregular de bienes raíces adscritos al sistema registral. Se debe recordar que no es lo mismo conocer el dominio ajeno, que reconocerlo, más allá de las limitaciones que puedan existir en la adquisición de la posesión de bienes raíces sujetos a inscripción registral.
}

${ }^{59}$ BarRientos (2016), pp. 940-941. Énfasis agregado. 
Se ha calificado como un "hecho jurídico. Así lo han resuelto la C.A. de San Miguel, en sentencia de fecha 7 de enero de 1987, G.J. No 80, p. 30 y RDJ., Tomo LXXXIV № 1, enero-abril de 1987"60. Así, se ha señalado que el precario, en su enfoque tradicional, "(...) es una figura a la que tiene acceso el propietario de una cosa para hacerse cargo de una situación de hecho incomoda, en que una cosa de su dominio es usada por otro "sin previo contrato y por ignoracia o mera tolerancia" suya" 61.

En términos similares, la Corte Suprema ha señalado que lo "característico del precario es constituir una simple situación fáctica ajena a toda relación contractual o acuerdo entre el tenedor de la cosa y su dueño. La tenencia que lo configura está desprovista absolutamente de todo antecedente jurídico, explicándose solo en la ignorancia o mera tolerancia de éste. Esa naturaleza no convencional que la propia norma explicita, la refuerza el legislador al expresar que esa tenencia es por ignorancia o mera tolerancia del dueño, reafirmando toda posibilidad de haber voluntad contractual o negocial. Al efecto esta Corte Suprema ha dicho que en el precario existe una simple situación de hecho, con absoluta ausencia de todo vínculo jurídico entre dueño y tenedor de la cosa, una tenencia meramente sufrida, permitida, tolerada o ignorada, sin fundamento, apoyo o título jurídicamente relevante en la cual el dueño ignora la ocupación de la cosa que le pertenece o bien, aunque la conoce, la tolera (Fallos del Mes, 1976, № 217, página 297)”62.

Como puede apreciarse, la naturaleza jurídica del precario sería la de una simple situación fáctica o de hecho, lo que en cierta medida se acerca a lo que dispone el inciso $2^{\circ}$ del art. 2195 CC. Ahora bien, según se expuso en el capítulo 3.- de la presente investigación, de una interpretación armónica del art. 2195 CC en su conjunto, se desprende que esta situación de hecho que contempla el inciso $2^{\circ}$ se asimila a la situación contractual regulada en su inciso $1^{\circ}$, conclusión que se desprende del propio texto de la ley. Recordemos que es dable sostener que el adverbio "también" fue utilizado por Bello como una manera de mantener dentro de la esfera contractual la situación de hecho que describe el inciso $2^{\circ}$ del art. 2195 CC, y ello, porque justamente mediante

\footnotetext{
${ }^{60}$ BarCIA (2007), p. 157, citando a VeGA (2002), pp. 19-20. Es del caso hacer presente que, si bien existen múltiples trabajos referidos al precario como institución que se revisaron para la preparación de este artículo, y que se encuentran debidamente citados en la bibliografía, ellos en general (con excepción de los citados en el cuerpo de la investigación) no analizan directamente la naturaleza jurídica del precario, como tampoco la del precarista.

${ }^{61}$ Larroucau y Rostion (2013), p. 42.

${ }^{62}$ Corte Suprema, rol № 23118-2014, de 1 de julio de 2015. Considerando Décimo Sexto. Énfasis agregado.
} 
dicho mecanismo se mantiene al denominado precarista dentro de la esfera de la mera tenencia.

De no ser ese el sentido del adverbio "también", no se explicaría la ubicación del Código Civil en que se reguló esta institución ${ }^{63}$. Por lo demás, aunque Bello dejó de lado el Derecho francés en esta parte, remitiéndose al Derecho romano, se debe tener presente que el precario en el Derecho romano con el paso del tiempo devino en un contrato innominado similar al comodato precario, por lo que no es de extrañar que si Bello lo reguló tomando como antecedente el Derecho romano, al haberlo incluido en la misma disposición del comodato precario y al utilizar el adverbio "también", son elementos que permiten sostener razonablemente que se pudo remitir a la época del Derecho romano postclásico y Justiniano, lo que dificulta todavía más sostener esta separación absoluta que se plantea recurrentemente entre el inciso $1^{\circ}$ y $2^{\circ}$ del art. 2195 CC.

Se reitera, una cosa es que el inciso $2^{\circ}$ del art. $2195 \mathrm{CC}$ se refiera a una situación fáctica, y otra muy distinta es dotarlo de una autonomía especial diversa a la del comodato precario, ya que ello no sólo genera una serie de dicotomías que se explicarán a lo largo de este trabajo, sino que dicha concepción simplemente no termina de cuadrar con la estructura del dominio, posesión y mera tenencia en que descansa nuestro Código Civil.

Según se adelantó, desde hace ya algunos años, la jurisprudencia en múltiples pronunciamientos ha expuesto que el precario y el comodato precario son figuras radicalmente distintas, toda vez que el primero sería una situación de hecho, mientras que el segundo, una variante del contrato de comodato en que se presenta alguna de las siguientes situaciones: "A. Se estipula que se podrá pedir la restitución de la cosa en cualquier momento; B. No se fija época para la restitución de la cosa; C. No se presta la cosa para un servicio determinado"64.

En directa relación con lo anterior, la Corte de Apelaciones de Valparaíso dictaminó: "Que, sin embargo, resulta evidente que, atendido el mérito de los antecedentes que obran en autos, existe una confusión entre el comodato

${ }^{63}$ En efecto, de haberse querido otorgar a esta institución la importancia y efectos que tuvo en el Derecho romano tradicional, lo más lógico hubiera sido regularla en el título de la posesión. Al encontrarse regulada como un tipo o especie del contrato de comodato precario, se demuestra que Bello nunca quiso separar esta particular situación de hecho de la figura de la mera tenencia. Se concuerda con Peñailillo, en el sentido que la acción de precario "por su ubicación y parquedad no parece haberse creado con tal transcendental destino". Véase: Peñallillo (2006), p. 536.

64 Selman (2011), p. 69. La referencia citada alude a la singularidad del precario como un estado del individuo sobre una cosa distinto a la mera tenencia y la posesión, siguiendo la posición mayoritaria de la jurisprudencia respecto al sentido o alcance del inciso $2^{\circ}$ del art. $2195 \mathrm{CC}$. En el presente trabajo, si bien la conclusión es similar considerando los requisitos que se deben cumplir para adquirir la posesión de bienes raíces sujetos a inscripción registral, se precisa el alcance del mismo, dependiendo de la interpretación que se siga respecto de la situación fáctica regulada en el inciso $2^{\circ}$ del art. 2195 CC. 
precario, demandado en el libelo de fojas 6 y el precario, que es la figura que efectivamente se regula en el artículo 2195 del Código Civil, dado que el primero se indica en el número anterior, esto es, en el artículo 2194 del mismo Código"65. En estos mismos términos, la Corte Suprema ha señalado: "b) que conforme con lo que disponen los artículos 2194 y el inciso primero del artículo 2195, el comodato precario es el convenio, contrato o acuerdo de las partes, en que el comodante entrega la cosa al comodatario reservándose en el primer caso la facultad de pedir la restitución de la cosa prestada en cualquier tiempo, y en el segundo, cuando no se presta la cosa para un servicio particular ni se fija tiempo para su restitución. Pero en todos estos casos tiene que haber un convenio entre las partes: el comodante entrega la cosa y el comodatario la recibe y se obliga a restituirla; c) que es materia totalmente diversa a lo que queda expresado, la que establece el inciso $2^{\circ}$ del artículo $2195(\ldots)^{\prime \prime 66}$

En este mismo sentido se han pronunciado nuestros tribunales superiores de justicia, por ejemplo, la Corte Suprema, en sentencia de reemplazo fecha 8 de agosto de 2007, dispuso: "Que el artículo 2195 del Código Civil, en su inciso segundo, dispone: "Constituye también precario la tenencia de una cosa ajena, sin previo contrato y por ignorancia o mera tolerancia del dueño. De lo anterior se desprende que un elemento inherente del precario constituye una mera situación de hecho, la total ausencia de vínculo jurídico entre el dueño y el tenedor del inmueble reclamado" ${ }^{\prime \prime 6}$.

El referido criterio se ha mantenido intacto en los últimos años, circunstancia que fue recalcada por la Corte Suprema en sentencia de fecha 9 de enero de 2013, que en lo pertinente dispuso: "Que la cuestión que se plantea en este recurso dice relación con una materia sobre la que esta Corte ha sentado una línea jurisprudencial. En efecto, conforme con las normas legales denunciadas como infringidas, se afirma que la sentencia impugnada habría errado la aplicación de la ley, al darle el carácter de contrato de comodato a una ocupación sin previo contrato, y que sólo traería como causa la ignorancia o la mera tolerancia del dueño de la propiedad cuya restitución se pretende, conforme se desprende del inciso segundo del artículo 2195 del Código Civil. En este sentido, esta Corte tiene dicho: "La disposición sustantiva en referencia, pone de manifiesto que un elemento inherente del precario constituye una mera situación de hecho,

\footnotetext{
${ }^{65}$ Corte de Apelaciones de Valparaíso, rol № 2203-2010, de 28 de marzo de 2011. Considerando Segundo.

${ }^{66}$ Corte Suprema, rol 12089, 21 de diciembre de 1976, disponible en Fallos del Mes, 1976, № 217, p. 299.

${ }^{67}$ Corte Suprema, rol № 2297-2006, de 8 de agosto de 2007. Considerando Primero de Sentencia de Reemplazo. Énfasis agregado.
} 
la total ausencia de vínculo jurídico entre el dueño y el tenedor del inmueble reclamado, carencia de nexo jurídico que justifica la acción de precario, toda vez que lo pedido a través de ella es la restitución o devolución de una cosa mueble o raíz (considerando vigésimo cuarto de la sentencia de esta Corte, rol $\left.\mathrm{N}^{\circ} 5986-2010\right)^{\prime \prime 68}$.

${ }^{68}$ Corte Suprema, rol No 5068-2011, de 9 de enero de 2013. Considerando Cuarto. Énfasis agregado. A efectos de demostrar la posición predominante de nuestra jurisprudencia a este respecto, a continuación, se detallan un conjunto de sentencias de nuestros Tribunales superiores del país que sostienen que el precario constituye una mera situación o cuestión de hecho. A saber: (i) Corte Suprema, rol 352152016, de 6 de julio de 2017; (ii) Corte Suprema, rol 5450-2017, de 30 de junio de 2017; (iii) Corte Suprema, rol 10227-2017, de 29 de junio de 2017; (iv) Corte Suprema, rol 65385-2016, de 29 de junio de 2017; (v) Corte Suprema, rol 10336-2017, de 28 de junio de 2017; (vi) Corte Suprema, rol 10261-2017, de 20 de junio de 2017; (vii) Corte Suprema, rol 300-2017, de 16 de junio de 2017; (viii) Corte de Apelaciones de Santiago, rol 13968-2016, de 13 de abril de 2017; (ix) Corte Suprema, rol 17686-2016, de 11 de abril de 2017; (x) Corte Suprema, rol 13798-2016, de 10 de abril de 2017; (xi) Corte Suprema, rol 14998-2016, de 4 de abril de 2017; (xii) Corte Suprema, rol 92845-2016, de 30 de enero de 2017; (xiii) Corte Suprema, rol 18856-2015, de 19 de enero de 2017; (xiv) Corte Suprema, rol 27191-2015, de 3 de enero de 2017; (xv) Corte de Apelaciones de Santiago, rol 6228-2016, de 26 de octubre de 2016; (xvi) Corte Suprema, rol 59030-2016, de 19 de octubre de 2016; (xvii) Corte Suprema, rol 55152-2016, de 17 de octubre de 2016; (xviii) Corte Suprema, rol 47543-2016, de 7 de septiembre de 2016; (xix) Corte Suprema, rol 10652-2015, de 18 de agosto de 2016; (xx) Corte Suprema, rol 7686-2015, de 8 de agosto de 2016; (xxi) Corte Suprema, rol 8233-2015, de 20 de julio de 2016; (xxii) Corte Suprema, rol 22244-2016, de 22 de junio de 2016; (xxiii) Corte Suprema, rol 4408-2015, de 30 de mayo de 2016; (xxiv) Corte Suprema, rol 17548-2016, de 18 de mayo de 2016; (xxv) Corte Suprema, rol 18315-2016, de 18 de mayo de 2016; (xxvi) Corte de Apelaciones de Santiago, rol 2745-2016, de 17 de mayo de 2016; (xxvii) Corte de Apelaciones de Santiago, rol 564-2016, de 26 de abril de 2016; (xxviii) Corte Suprema, rol 37641-2015, de 30 de marzo de 2016; (xxix) Corte Suprema, rol 3276-2015, de 29 de marzo de 2016; (xxx) Corte Suprema, rol 34203-2015, de 8 de marzo de 2016; (xxxi) Corte de Apelaciones de Iquique, rol 819-2015, de 22 de febrero de 2016; (xxxii) Corte de Apelaciones de Copiapó, rol 417-2014, de 18 de diciembre de 2015; (xxxiii) Corte Suprema, rol 29095-2014, de 10 de diciembre de 2015; (xxxiv) Corte Suprema, rol 313492014, de 20 de noviembre de 2015; (xxxv) Corte Suprema, rol 8433-2015, de 16 de noviembre de 2015; (xxxvi) Corte de Apelaciones de Talca, rol 1539-2015, de 30 de octubre de 2015; (xxxvii) Corte Suprema, rol 27168-2014, de 29 de octubre de 2015; (xxxviii) Corte de Apelaciones de Santiago, rol 9156-2015, de 16 de octubre de 2015; (xxxix) Corte Suprema, rol 24411-2014, de 22 de septiembre de 2015; (xl) Corte de Apelaciones de Concepción, rol 908-2015, de 4 de agosto de 2015; (xli) Corte de Apelaciones de San Miguel, rol 941-2015, de 31 de julio de 2015; (xlii) Corte de Apelaciones de Valparaíso, rol 692-2015, de 23 de junio de 2015; (xliii) Corte de Apelaciones de Santiago, rol 2572-2015, de 29 de mayo de 2015; (xliv) Corte Suprema, rol 3529-2015, de 27 de mayo de 2015; (xlv) Corte Suprema, rol 2631-2014, de 2 de octubre de 2014; (xlvi) Corte Suprema, rol 129062013, de 30 de septiembre de 2014; (xlvii) Corte Suprema, rol 8489-2013, de 4 de junio de 2014; (xlviii) Corte de Apelaciones de Iquique, rol 8-2014, de 6 de mayo de 2014; (xlix) Corte Suprema, rol 4018-2012, de 4 de julio de 2013; (I) Corte Suprema, rol 2357-2011, de 4 de diciembre de 2012; (li) Corte Suprema, rol 8507-2009, de 7 de abril de 2011; (lii) Corte Suprema, rol 2351-2009, de 19 de octubre de 2010; (liii) Corte Suprema, rol 5907-2008, de 12 de noviembre de 2009; (liv) Corte Suprema, rol 6510-2007, de 24 de noviembre de 2008; (Iv) Corte Suprema, rol 5604-2006, de 12 de noviembre de 2007; (Ivi) Corte Suprema, rol 3142-2004, de 22 de mayo de 2006; (Ivii) Corte Suprema, rol 47542003, de 14 de diciembre de 2004; (Iviii) Corte de Apelaciones de Puerto Montt, rol 10565-2002, de 
De las sentencias recién citadas, se denota la diferencia que se ha marcado en la jurisprudencia entre la figura descrita en el inciso $2^{\circ}$ del art. 2195 CC y el comodato precario, como asimismo que el precario constituye una mera situación o cuestión de hecho. En lo que se refiere a la elaboración conceptual del precario, la doctrina contemporánea ha sido consistente en considerar que aquel implica una situación de hecho en los términos descritos en el inciso $2^{\circ}$ del art. 2195 CC. Así, por ejemplo, Halabí y Saffirio sostienen que el precario "Es una situación de hecho en que una persona, denominada precarista, goza de una cosa singular y determinada, mueble o raíz, sin previo contrato y por ignorancia o mera tolerancia del dueño" ${ }^{\prime 69}$. En términos similares se pronuncia Ramos Pazos, quien al respecto señala: “(...) No hay comodato precario, porque no hay contrato, hay simplemente una cuestión de hecho que es mejor llamar precario" ${ }^{\prime \prime 7}$.

Es decir, el precario vendría a ser una situación de hecho que implica una ausencia total de vínculo jurídico entre el dueño de la cosa y el llamado precarista. Si bien todos estos pronunciamientos en lo literal son acertados, no reparan respecto de la asimilación que el propio articulado dispone entre el inciso $2^{\circ} \mathrm{y}$ el inciso $1^{\circ}$ del art. $2195 \mathrm{CC}$.

En este orden de ideas, y de conformidad a lo resuelto por la doctrina y la jurisprudencia, es dable sostener que: A) El precario difiere de la figura contractual del comodato precario. En otras palabras, el precario no es un contrato ni se asimila a él; B) El precario es una situación de hecho en los términos dispuestos en el inciso $2^{\circ}$ del art. 2195 CC.

Las conclusiones antes referidas, sin perjuicio de significar un avance importante en cuanto a la naturaleza jurídica del precario, no resultan suficientes a la hora de determinar la naturaleza jurídica del precarista, aunque fijan ciertas directrices que permiten delimitar a este último a un número reducido de situaciones, facilitando la elaboración de una tesis sobre su naturaleza jurídica. En efecto, entender la naturaleza jurídica del precario como una situación de hecho -sin asimilarla a la figura contractual del comodato precario-, tiene como consecuencia necesaria que el precarista no podría ser un mero tenedor en su concepción clásica, que lo asocia a un derecho real o personal, y aunque

15 de abril de 2002; (lix) Corte de Apelaciones de Santiago, rol 1743-2000, de 22 de enero de 2002; (Ix) Corte Suprema, 31 de julio de 1986, disponible en Gaceta Jurídica № 73, y citada en BarRIENTOS (2016) pp. 940-941; (Ixl) Corte de Apelaciones San Miguel, rol 530-1986, 27 de noviembre de 1986, disponible en Thomson Reuters - WestLaw Cita Online: CL/JUR/268/1986.

${ }^{69}$ Halabí y Saffirio (1996), p. 11.

${ }^{70}$ Ramos (1986), p. 8; quien a su vez hace referencia a Ramos (1982), p. 2. 
podría serlo en una concepción moderna, deberá analizarse previamente si éste reconoce dominio ajeno en los términos del inciso $2^{\circ}$ del art. $714 \mathrm{CC}$.

\section{Dualidad del precarista}

\subsection{Situaciones de hecho intermedias que pueden perturbar el dominio}

Antes de comenzar el análisis del presente capítulo, es importante clarificar que en el día a día se generan ciertas situaciones de hecho intermedias que pueden perturbar la titularidad del dominio, sin que el que perturba dicha calidad ostente necesariamente un título que justifique la utilización de la cosa, sea ésta mueble o inmueble.

En efecto, y pese que para algunos resulta de Perogrullo que el precarista como tal debe reconocer dominio ajeno (en cuyo caso sería un mero tenedor), Ilama la atención como algunos autores se refieren, con justa razón, al peligro que suponen los detentadores materiales, esto es, personas que tienen una cosa en su poder sin reconocer dominio ajeno. En este sentido, por ejemplo, Tapia, señala: "(...) como ya se expuso, no todos los sujetos pasivos de esta acción son o pueden ser "meros tenedores", esto es, detentadores que reconocen dominio ajeno y que, por tanto, no son una amenaza para el dominio del actor. La acción del artículo 915 puede intentarse, y así lo prueba alguna jurisprudencia y la opinión de ciertos autores, contra el "detentador material", que es simplemente quien tiene en su poder la cosa, sin reconocer dominio ajeno. Por ejemplo, el que tiene la cosa sin título alguno. Y, más allá de tecnicismos, quien tiene una cosa sin reconocer dominio ajeno, es también una potencial amenaza para el propietario. No es poseedor, pero puede transformarse en uno, fácilmente en el caso de los muebles, y de forma un poco más compleja en el caso de los inmuebles. ¿Acaso el Decreto Ley № 2.695 (de regularización de la pequeña propiedad raíz) no tiene en último término ese efecto en muchos casos? (... $)^{\prime \prime 1}$.

En efecto, existe cierto conceso a nivel doctrinario en el sentido de que el precarista es un mero tenedor (por descarte), lo que no obsta sus cualidades particulares en los términos dispuestos en el inciso $2^{\circ}$ del art. 2195 CC. Entonces, bajo una óptica tradicional, es posible concebir al dueño, al poseedor, y al mero tenedor (el precarista sería un tipo especial de mera tenencia). Asimismo, también se reconocen ciertas situaciones fácticas que escapan a las situaciones antes indicadas, las que son posibles calificar como situaciones intermedias, así, sería el caso de quien, sin título, y sin reconocer dominio ajeno, posee materialmente un bien raíz sin la correspondiente inscripción registral. En este orden de ideas, bajo el sistema comúnmente aceptado, es posible afirmar que

71 TAPIA (2015), p. 417. Énfasis agregado. 
existen ciertas situaciones de hecho, que no se circunscriben en el dominio, posesión ni mera tenencia, y que, pese a ello, son de común recurrencia en los Tribunales de justicia, en que, a través de la jurisprudencia, se ha intentando resolver esta problemática, utilizando al efecto la acción contemplada en el art. 915 CC o bien la acción de precario, como salvaguarda a dichas situaciones intermedias. Lo anterior, de por sí, genera una dicotomía no menor, ya que desde un punto de vista dogmático se delimita la figura del precario tomando como fundamento su sentido o alcance histórico, mientras que, en la práctica, contra ese mismo precarista, en algunas hipótesis se puede terminar litigando sobre el dominio de la cosa.

El problema radica en que algunos sostienen como supuesto inalterable que el precarista, de acuerdo con la regulación que tiene en nuestro Código Civil, necesariamente reconoce dominio ajeno, cuando en los hechos, al ejercer la acción de precario, dicha calidad dependerá de la defensa que esgrima el demandado, ya que, si éste opone una demanda reconvencional de prescripción adquisitiva extraordinaria o defiende su calidad de poseedor (aunque sea irregular), probablemente la controversia deberá resolverse en un juicio de lato conocimiento. En efecto, "La procedencia de la acción de precario requiere que al actor le asista la calidad indubitada de dueño del bien cuya restitución solicita y que se encuentra ocupado por un tercero sin título alguno o por su mera tolerancia, por lo que para que esta acción prospere es indispensable que la demandada no discuta el dominio de dicho bien (CA. Valparaíso, 12-IX-2000, $\mathrm{N}^{\circ}$ LegalPublishing: 18233, rol № 4028-2000)"72

Como veremos, entre los requisitos objetivos de aplicación de la acción de precario según lo dispuesto en el art. 2195 CC, a juicio de quien escribe, no se encuentra el animus con que el demandado detenta la cosa, más allá que dogmáticamente, y tomando como punto de partida el sentido histórico de esta institución en el Derecho romano primitivo, en efecto, el precarista reconoce dominio ajeno.

\subsection{Estados en que un individuo puede encontrarse frente a una cosa}

Aclarado lo anterior, el Código Civil chileno establece los diversos estados en que un individuo puede encontrarse frente a una cosa, cuestión que se encuentra, en primer lugar, recogida en el mensaje (\$24) del Código Civil, y, en segundo lugar, en el libro segundo del referido cuerpo legal, quedando establecido que un individuo puede revestir, en una primera aproximación, las calidades de dueño, poseedor o mero tenedor sobre una cosa.

72 BarRientos (2016), pp. 952-953. Énfasis agregado. 
Tal y como se adelantó en los capítulos precedentes, la figura del precario parece no haber sido prevista por Bello en los términos que se aplica en la actualidad, quien, por lo demás, se preocupó de establecer con recelo las principales características del dominio, la posesión y la mera tenencia. En estos términos, el mensaje del Código Civil (\$24) es clarificador, especialmente aquella parte que señala: "El que a nombre ajeno posee, no es más que un representante del verdadero poseedor, ni inviste más que la simple tenencia. Así los términos, posesión civil, posesión natural, son desconocidos en el proyecto que os someto; las palabras posesión y tenencia contrastan siempre en él". Es decir, fuera del ámbito de la posesión -y el dominio-, se encuentra la mera tenencia, que circunscribiría a su respecto todas aquellas situaciones en que un individuo detente una cosa sin revestir las calidades de dueño o poseedor. Asimismo, se ha defendido a lo largo de estas páginas que la situación de hecho, que contempla el inciso $2^{\circ}$ del art. 2195 CC, es asimilable a la figura contractual de su inciso $1^{\circ}$, en cuyo supuesto el precarista sin lugar a dudas sería un mero tenedor, lo que se encuentra en absoluta armonía con el mensaje y disposiciones del Código Civil.

Con todo, y fuera de la disquisición anterior, se ha señalado por la doctrina que el precarista, no pudiendo encuadrarse en el dominio y la posesión, estaría relegado -necesariamente- a la figura de la mera tenencia. Esta idea es sostenida por Barrientos, quien al respecto señala: "Para el Código Civil, pues, el hecho de tener una cosa bajo un cierto control efectivo material, o es posesión o es tenencia. No hay otra posibilidad. De guisa que el invasor de una heredad, no siendo poseedor de ella por carecer de inscripción, es sólo su mero tenedor. $\mathrm{Y}$, además, este simple tenedor que carece de todo título no translaticio de dominio es jurídicamente un precarista, al tenor, de lo dispuesto en el inciso $2^{\circ}$ del artículo 2195 del Código Civil"73. Acto seguido, el citado autor clasifica al mero tenedor en dos grupos, a saber: A) aquellos que tienen una cosa fundado en un título no traslaticio de dominio; y B) aquellos que derechamente detentan una cosa sin ningún título justificativo, opción última donde se encontraría el precarista. La conclusión arribada por Barrientos, permite encasillar al precarista -figura esencialmente desarrollada en la jurisprudencia- dentro del sistema establecido en el Código Civil chileno, logrando mantener intacta la Ilamada trilogía jurídica ${ }^{74}$. El problema de tal postura es que el art. 714 CC no circunscribe a su respecto -en opinión de quien escribe- aquellos casos que una persona detente una cosa ajena sin reconocer dominio ajeno, o incluso

73 BarRientos (2005), p. 230. Énfasis agregado.

${ }^{74}$ Alessandri y Somarriva (1974), p. 453. 
con ánimo de señor o dueño ${ }^{75}$, sin un título justificativo, por ignorancia o mera tolerancia del dueño ${ }^{76}$.

\subsection{Concepto de mero tenedor de acuerdo con el art. 714 CC.}

Para explicar lo anterior, resulta necesario analizar detalladamente el contenido de ambos incisos del art. 714 CC, lo que permitirá dilucidar si la figura de la mera tenencia es capaz de circunscribir a su respecto, todas aquellas situaciones en que un individuo detente un bien corporal sin revestir las calidades de dueño o poseedor. Al respecto, el inciso $1^{\circ}$ del art. 714 CC establece que: "Se llama mera tenencia la que se ejerce sobre una cosa, no como dueño, sino en lugar o a nombre del dueño. El acreedor prendario, el secuestre, el usufructuario, el usuario, el que tiene el derecho de habitación, son meros tenedores de la cosa empeñada, secuestrada, o cuyo usufructo, uso o habitación les pertenece". Resulta evidente que la norma recién transcrita conceptualiza la mera tenencia como aquella que se ejerce sobre una cosa en virtud de un título no traslaticio de dominio.

Por su parte, el inciso $2^{\circ}$ del art. 714 CC señala: "Lo dicho se aplica generalmente a todo el que tiene una cosa reconociendo dominio ajeno". Lo anterior, ciertamente, dificulta la delimitación de la mera tenencia, puesto que incluye a su respecto todos aquellos casos en que una persona, reconociendo dominio ajeno, detenta una cosa que no le pertenece, no interesando para tales efectos si dispone de un título que lo justifique a utilizar la cosa. Sin perjuicio de la amplitud que otorga inciso $2^{\circ}$ del art. 714 CC, lo que podría llevar a sostener que tal disposición hace las veces de cajón de sastre, resulta interesante detenerse en aquella parte que señala que, para ser mero tenedor, necesariamente, se debe reconocer dominio ajeno. En efecto, bajo el prisma del inciso en análisis, jamás podría considerarse mero tenedor aquel individuo que, detentando una cosa ajena, no reconoce dominio ajeno, en cuyo caso por defecto estaríamos frente a un simple detentador, o bien ante un poseedor irregular o una figura con

\footnotetext{
75 Dicha hipótesis presupone separar completamente la situación de hecho del inciso $2^{\circ}$ del art. 2195 CC de aquella descrita en el inciso $1^{\circ}$, ya que, a contrario sensu, la referida situación fáctica sería asimilable al contrato de comodato precario, en el cual se reconoce dominio ajeno, y por ende el precarista sería un mero tenedor en los términos del art. 714 CC.

76 El art. 590 CC, señala que "Son bienes del Estado todas las tierras que, estando situadas dentro de los límites territoriales, carecen de otro dueño". En este entendido, y en la hipótesis de utilizar un bien raíz con ánimo de señor o dueño, estaríamos frente a un poseedor irregular o un detentador con rasgos posesorios (ver nota al pie de página $N^{\circ} 77$ ), ya que el inmueble, o bien pertenece a otra persona, o bien al Estado de Chile, no hay otra posibilidad.
} 
rasgos posesorios ${ }^{77}$, en la hipótesis que, además de no reconocer dominio ajeno, detente la cosa con ánimo de señor o dueño ${ }^{78}$, siempre que no se considere la inscripción registral como prueba absoluta de la posesión ${ }^{79}$.

77 Respecto a la posibilidad de ser poseedor irregular sin título alguno se ha señalado lo siguiente:
"De esto se sigue que el poseedor irregular puede no tener título alguno que invocar, mala fe, porque tiene conciencia de que ha recibido la cosa de quien no es legítimo dueño o lo ha hecho de quien no tenía facultad para enajenar o con fraude o vicios; o, finalmente, no se le ha hecho tradición de la cosa a pesar de tener título traslaticio de dominio. ¿Qué tiene entonces, necesariamente el poseedor irregular? La tenencia material de la cosa. Este es el único requisito objetivo que debe concurrir. Pero, además, debe concurrir un requisito negativo. No puede invocar un título de mera tenencia porque, salvo el caso de la regla tercera del artículo 2510 del Código Civil, este título le impediría adquirir por prescripción (ninguna importancia tiene que se le presuma mala fe). En el fondo, el poseedor irregular no tiene más que la cosa, la detenta sin derecho alguno y con la conciencia de no ser dueño. En definitiva, el animus domini se presume, aun cuando la ley no lo diga expresamente". Véase: RODRíGUez (1994), pp. 28-29. Siguiendo esta postura, la redacción del art. 708 CC señala que la posesión irregular es aquella a la que le falta "uno o más" de los requisitos de la posesión regular. Asimismo, la $1^{\mathrm{a}}$ regla del art. 2510 CC señala que para la prescripción extraordinaria no es necesario título alguno. Incluso más, en el art. 703 CC la ocupación es calificada como título, y en ese sentido sería posible sostener que la simple ocupación hace las veces de título, aunque se considere injusto. Al tratarse la ocupación como título en el art 703 CC, se podría argumentar -no sin discusión-, que aun cuando el art. 606 CC señala que solo se puede adquirir por ocupación bienes que no pertenecen a nadie, ello se encuentra circunscrito en el tratamiento de la ocupación como modo de adquirir el dominio y no como título que habilite esgrimir la prescripción adquisitiva extraordinaria. Una interesante reflexión de lo expuesto precedentemente en PeÑalıLLo (2006), p. 421 (véase nota al pie de página $\mathrm{N}^{\circ} 631$ de su obra). Lo anterior, además, supondría adherir a la teoría que postula la posibilidad de adquirir la posesión irregular de inmuebles adscritos al sistema registral, aun cuando no se realice la competente inscripción (Véase: Álvarez (1926), pp. 15-25), ello sin perder de vista que los títulos constitutivos de dominio no requieren inscripción. Ahora bien, la situación se vuelve más compleja aún en los casos de aquellos "precaristas" que tienen un título, pero este proviene de un tercero distinto al dueño. Como se mencionó al inicio de este trabajo, parte de la jurisprudencia considera como precaristas a quienes justifican su ocupación en un título emanado de un tercero distinto al dueño. En dicha hipótesis, y siempre que se considere que es posible adquirir la posesión irregular sin la competente inscripción como lo ha señalado alguna jurisprudencia más o menos reciente (véase: Corte Suprema, rol 39182011, de 4 de abril de 2012), se hace más patente todavía la dualidad que puede presentar el precarista. Por el contrario, en caso de adherir a la postura (mayoritaria) que sostiene que toda posesión, sea regular o irregular, requiere de un título, justo o injusto según corresponda, y descartando que la ocupación pueda subsanar la ausencia de título, de acuerdo a lo planteado en estas páginas, y a la forma en que se ha interpretado por nuestros tribunales de justicia el inciso $2^{\circ}$ del art. 2195 CC, estaríamos frente a un detentador material que no es mero tenedor, ya que tiene la cosa con ánimo de señor o dueño, pero que tampoco alcanza a ser poseedor irregular, aunque ostente los elementos de corpus y animus del art. $700 \mathrm{CC}$. Con todo, no se debe perder de vista que todo aquel que detente un inmueble ajeno con ánimo de señor o dueño, aunque carezca de título, es un potencial peligro para el dueño de la cosa.

${ }^{78} \mathrm{Si}$ bien podría darse un supuesto hipotético en que el detentador material no reconozca dominio ajeno, y a la vez no tenga la cosa con ánimo de señor o dueño, lo más probable es que, o bien reconozca dominio ajeno, o bien no lo reconozca aludiendo ánimo de señor o dueño.

${ }^{79}$ Sin perjuicio de lo que se señalará en el capítulo 7.- a este respecto, debido a que varios de los argumentos que se expondrán a continuación razonan sobre la inscripción registral, se adelanta que en Chile existen dos teorías sobre los alcances probatorios de la inscripción registral en los bienes raíces, 
Es importante destacar que la doble acepción de la mera tenencia que comprende el art. 714 CC ya ha sido objeto de análisis por parte de la jurisprudencia, así por ejemplo la Corte de Apelaciones de Valdivia, mediante sentencia de fecha 4 de marzo de 2008, dispuso lo siguiente: "Que esta Corte entiende que la mera tenencia, en el marco conceptual del Derecho Civil, tiene una doble acepción. Por una parte, la idea se refiere a la situación jurídica clásica en la que una persona tiene la cosa a nombre y en lugar de otro, en virtud de un título no traslaticio de dominio (o título de mera tenencia), como el arriendo, el comodato o la prenda. A esa acepción hace referencia la sentencia de primer grado cuando entiende que no se ha probado la mera tenencia porque no se ha establecido a nombre de quien se ha tenido el inmueble; y es la acepción a que aluden (a título ilustrativo) los artículos 700, 714 y 2510 regla $3^{\text {a }}$ del Código Civil. Pero también el Código acepta bajo la idea de mera tenencia una situación meramente de facto, distinta de la anterior, consistente en la pura detentación de la cosa, sin ánimo de señor (sino sólo de aprovechamiento material, sumado, en este caso, a la expectativa de que el dueño -el Fisco de Chile- realice a favor del detentador una liberalidad, transfiriendo el dominio), detentación permitida por la mera tolerancia o por el desconocimiento del dueño. Esta situación de hecho, en la que no hay título, es asimilada por la ley a la mera tenencia, como se aprecia ya en el inciso segundo del citado artículo 714, que dispone que lo dicho se aplica generalmente a todo el que tiene una cosa reconociendo dominio ajeno, y muy especialmente, a propósito del precario en el artículo 2195 del Código Civil, que expresa con claridad que constituye también precario la tenencia de una cosa ajena, sin previo contrato y por ignorancia o mera tolerancia del dueño" 80 .

Si bien la sentencia en comento resalta la diferencia notada precedentemente, a propósito de la doble acepción de la mera tenencia, entiende derechamente al precarista (en cualquier hipótesis) como un mero tenedor. Si bien no se comparte esa postura en particular (bajo el contexto de la interpretación actual de la jurisprudencia que prima respecto al sentido o alcance del inciso $2^{\circ}$ del art. 2195 $\mathrm{CC})$, la sentencia reconoce que la detentación de una cosa ajena sin ánimo de señor, por ignorancia o mera tolerancia del dueño, configura una mera tenencia,

\footnotetext{
la denominada (i) inscripción-ficción, en que la inscripción realizada en el Registro de Propiedad del Conservador de Bienes Raíces respectivo, es prueba absoluta de la posesión, dejando de lado los elementos propios de la posesión como el corpus y animus, y la llamada (ii) inscripción-garantía, en la cual se da preponderancia a los elementos propios de la posesión, corpus y animus; mientras que la inscripción conservatoria no tiene otro alcance más que favorecer y proteger ese estado de hecho, pero jamás podrá reemplazar los elementos propios de la posesión contemplados en el art. 700 CC.

${ }^{80}$ Corte de Apelaciones de Valdivia, rol № 762-2007, de 4 de marzo de 2008. Considerando Tercero. Énfasis agregado.
} 
conclusión que se comparte siempre que se reconozca dominio ajeno, con la variante que aquí se sostiene además, la posibilidad que ese mismo sujeto que detenta la cosa, lo haga, sin reconocer dominio ajeno, e incluso con ánimo de señor o dueño, ello siempre en la hipótesis de que no se entienda asimilable la situación de hecho del inciso $2^{\circ}$ del art. 2195 CC respecto de aquella contractual descrita en el inciso $1^{\circ}$ del referido articulado, en cuyo caso el precarista será, sin lugar a dudas, un mero tenedor.

En efecto si se parte del supuesto de que el precario es una situación de hecho no asimilable al contrato de comodato precario, y el inciso $2^{\circ}$ del art. 714 CC señala que sólo será mero tenedor aquel que reconoce dominio ajeno, el precarista, entendiendo por tal aquella persona descrita en el inciso $\mathbf{2}^{\circ}$ del art. 2195 CC, podría detentar la cosa ajena sin reconocer dominio ajeno e incluso con ánimo de señor o dueño ${ }^{81}$, no resultando aplicable en su contra la regla de inmutabilidad del art. 716 CC, ya que, si desde un inicio no reconoció dominio ajeno, o bien, comenzó a detentar la cosa con ánimo de señor o dueño, nunca fue mero tenedor. Por lo demás, "El artículo 714 dispone en su inciso $2^{\circ}$ "Lo dicho (o sea, son meros tenedores) se aplica generalmente a todo el que tiene una cosa reconociendo dominio ajeno". Basta leer el citado precepto para darse cuenta de que una cosa es conocer el dominio ajeno y otra, muy distinta, reconocerlo. En efecto, conocer algo es saber su existencia; reconocer, en cambio, es respetar. El que tiene una cosa a nombre del dueño o en su lugar, indudablemente reconoce el dominio ajeno; pero el ladrón, que posee en su propio nombre, y con un marcado animus, de ninguna manera reconoce el dominio ajeno, puesto que no lo respeta" ${ }^{\prime 2}$.

Peñailillo también ha reconocido el sentido o alcance del art. 714 CC, aunque en su opinión, la definición que otorga el referido articulado no se encuentra bien construida, por cuanto a su parecer no le parece "necesario el reconocimiento de dominio ajeno; también hay que calificar de mero tenedor al que simplemente detenta la cosa (sin ánimo de dueño) sin tener reflexión

81 Ello, claro está, dependiendo de la postura que se adopte respecto al valor de la inscripción registral y de las características que se consideren aplicables para ser considerado un poseedor irregular (ver nota al pie de página $N^{\circ} 77$ ). En efecto, de estimarse que la inscripción registral en la única prueba de la posesión de los bienes raíces adscritos al sistema registral, aquella persona que tenga una cosa ajena con ánimo de señor o dueño se circunscribiría en los supuestos de aplicación del inciso $2^{\circ}$ del art. 2195 CC de acuerdo a lo señalado por la jurisprudencia, y podría considerarse un precarista ya que nunca podría obtener la posesión del bien, entendiendo que ella se obtiene únicamente con la debida inscripción en el Registro de Propiedad del Conservador de Bienes Raíces respectivo. Por el contrario, de restarse valor a la inscripción, y siguiendo la postura que justifica la posibilidad de ser poseedor irregular sin título, estaríamos frente a un poseedor irregular. Para mayores detalles véase el capítulo 7.- del presente artículo.

82 Belmar (2010), p. 583. Énfasis agregado. 
alguna acerca de si tiene dueño o no. Entonces, lo importante no es el reconocimiento de dominio ajeno, sino la convicción de que la cosa no es propia" ${ }^{\prime \prime 3}$. En términos similares se refiere Orrego ${ }^{84}$, quien haciendo especial énfasis a la deficiencia en la construcción del art. 714 CC, y siguiendo a Peñailillo, concluye en términos similares.

Si bien la postura de los autores antes citados, mantiene una armonía con lo resuelto por la jurisprudencia de forma uniforme en el último tiempo, respecto al sentido o alcance que se ha atribuido al inciso $2^{\circ}$ del art. 2195 CC, ello requiere necesariamente alejarse del tenor literal del inciso $2^{\circ}$ del art. 714 CC que únicamente otorga el carácter de mero tenedor a aquellos que reconocen dominio ajeno ${ }^{85}$.

Recordemos que, mediante la presente investigación, se pretende postular una posición alternativa al alcance que ha atribuido la jurisprudencia al inciso $2^{\circ}$ del art. 2195 CC, en el sentido que el precarista, si bien podrá ser considerado a todo evento un mero tenedor, ello ocurrirá siempre que el precario se asimile a la figura contractual del contrato de comodato precario, mas no por una interpretación extensiva de la definición de mero tenedor que señala expresamente el art. 714 CC.

\subsection{Relación entre el inciso $2^{\circ}$ del art. 2195 CC y el art. 714 CC}

En virtud de la posición que impera en nuestra jurisprudencia respecto al sentido o alcance del precario, perfectamente podría darse el caso de un individuo que comienza a utilizar un retazo de terreno ajeno, y al mismo tiempo, en su fuero interno, no reconozca dominio ajeno o incluso lo ocupe con ánimo de señor o dueño. En el caso antes descrito, y de acuerdo al tenor literal del art. 714 CC, malamente se podría sostener que aquel individuo es un mero tenedor, toda vez que no reconoce dominio ajeno e incluso se pretende dueño de la cosa. Por lo demás, esta especial situación de hecho es muy similar a la teoría de la "posesión material", conforme a la cual la jurisprudencia ha justificado la procedencia de la acción reivindicatoria en contra de aquel sujeto que, sin reconocer dominio ajeno, detenta un inmueble sin inscripción a su nombre, en razón que la posesión material del ocupante-considerando como una situación distinta de la mera tenencia- vulneraría la posesión del dueño, al privarlo "de

\footnotetext{
83 Peñailillo (2006), p. 361 (véase nota al pie de página № 523 de su obra).

${ }^{84}$ Orrego (2015), pp. 211-212.

85 Por lo demás, de acuerdo con lo dispuesto en el art. 19 CC, "cuando el sentido de la ley es claro, no se desatenderá su tenor literal, a pretexto de consultar su espíritu".
} 
una parte integrante de la posesión, su fase material"86. Como puede apreciarse, situaciones de hecho como la descrita precedentemente se encuadran dentro del concepto de precario que ha acuñado la jurisprudencia (situación de hecho sin vínculo contractual alguno), lo que si bien no se ajusta al concepto de precario del Derecho romano primitivo, ya se indicó que el precario en Chile, tanto por su escueta regulación como por su ubicación en el Código Civil, difícilmente se concibió por Bello en dichos términos, bajo su estructura clásica, que permita por esa sola apreciación, con la intención de recobrar la sede histórica del precario, asumir sin más que el precarista presupone el reconocimiento de dominio ajeno, siendo que el precario como institución se ha conceptualizado por la jurisprudencia chilena como una situación de hecho, con ausencia de un vínculo jurídico entre el dueño de la cosa y el tenedor del inmueble.

Se estima que el animus del precarista, si bien no tiene mayores efectos frente a la teoría de la posesión inscrita, marca una diferencia de aquel individuo que reconoce dominio ajeno. Recordemos que si se considerase la situación descrita en el inciso $2^{\circ}$ del art. 2195 CC como una figura asimilable al comodato precario, el precarista necesariamente sería un mero tenedor, pero si se considera el precario como una situación de hecho distinta -y no asimilable- al comodato precario, no queda clara la posibilidad de circunscribir a su respecto la regla del art. 714 CC. La dicotomía antes descrita se debe a que la figura del precario se ha asimilado a aquella contemplada en el Derecho romano primitivo, mientras que la regulación introducida Bello, aunque tomó en consideración la regulación romana, no la separó, a juicio del autor, completamente del comodato precario, asimilándola en sus efectos a dicho contrato mediante la utilización del adverbio "también". Por lo mismo, la posibilidad de comprender que el precarista puede llegar a detentar una cosa sin reconocer dominio ajeno e incluso con ánimo de señor o dueño se justifica única y exclusivamente en el desarrollo jurisprudencial del precario como una figura ajena y no asimilable al comodato precario.

En este orden de ideas, y bajo el supuesto antes descrito, se encasillará en la figura de la mera tenencia todo individuo que ocupe una cosa reconociendo

\footnotetext{
${ }^{86}$ Peñallitlo (2006), p. 531. Sin perjuicio que esta teoría se enfoca en la fase material de la posesión, sin hacer mayor referencia al animus del ocupante, podría darse la situación que el demandado de reivindicación bajo dicho presupuesto, además detente la cosa con ánimo de señor o dueño. En otras palabras, la jurisprudencia ya ha distinguido al mero tenedor del "poseedor material", tomando como punto de referencia la fase material que comprende la posesión, por lo que, si añadimos el animus del individuo, dicha situación se alejará aún más de la mera tenencia. Lo anterior viene a demostrar que la extensión del concepto de mera tenencia a situaciones en que no existe reconocimiento de dominio ajeno, se contrapone abiertamente a otras construcciones jurisprudenciales, en que incluso por el solo hecho de detentar una cosa ajena una persona puede considerase "poseedor material" -y no mero tenedor-, pudiendo aplicarse en su contra la acción reivindicatoria.
} 
dominio ajeno, sin importar para tales efectos si dispone o no de un título no traslaticio de dominio. Por el contrario, si el precarista no reconoce dominio ajeno, estaremos frente a una situación que no termina de cuadrar con las figuras clásicas de dominio, posesión o mera tenencia, lo que incluso permite sostener que estaríamos ante un nuevo estado del individuo frente a una cosa.

Bajo el supuesto antes descrito, sería posible subdividir al precarista en dos grandes hipótesis, la primera de ellas, en que se reconoce dominio ajeno, en cuyo caso calificaría como un mero tenedor, y en la segunda, no se reconoce dominio ajeno, esta última, con la posibilidad de utilizar la cosa con ánimo de señor o dueño. Esta división se encuentra conforme a lo dispuesto en el inciso $2^{\circ}$ del art. 714 CC. En efecto, dicho artículo hace suyos aquellos casos en que se detenta una cosa ajena sin contrato, pero con la salvedad de que se reconozca dominio ajeno. A su vez, se ha interpretado por la jurisprudencia que el inciso $2^{\circ}$ del art. $2195 \mathrm{CC}$ describe una situación de hecho, no asimilable al comodato precario, en que se tiene una cosa ajena, sin título o contrato, por ignorancia o mera tolerancia del dueño. Pues bien, bajo tales presupuestos, el precarista perfectamente podría serlo reconociendo dominio ajeno, o bien sin reconocer dominio ajeno, e incluso con ánimo de señor o dueño ${ }^{87}$, independiente que la aplicabilidad de esta última hipótesis (en el entendido que continúe considerándose un precarista y no un poseedor irregular o una figura con rasgos posesorios $\left.{ }^{88}\right)$, depende en gran medida de una aplicación irrestricta de la teoría de la inscripción-ficción, ya que en caso contrario estaríamos frente a un detentador que dependiendo de la postura que se siga, podría incluso llegar a considerarse poseedor irregular ${ }^{89}$.

\subsection{La mera tolerancia del dueño y sus posibles efectos en la dualidad del precarista}

Ahora bien, resulta de suma relevancia referirse a aquellos casos en que el precarista lo es por mera tolerancia del dueño. En efecto, en los casos en que exista ignorancia del dueño no hay mayor dificultad a su respecto. Distinto es el caso de la mera tolerancia, concepto cuyo real significado no es unánime en la doctrina y jurisprudencia. Por ejemplo, Alessandri y Somarriva plantearon al respecto que: "Los actos de mera tolerancia no están definidos por la ley. Pero

\footnotetext{
${ }^{87}$ Haciendo la salvedad que en los casos en que exista mera tolerancia de parte del dueño de la cosa, difícilmente el precarista podrá acreditar su ánimo de dueño. Es del caso señalar que el ánimo de señor o dueño debe ser real, cuestión que deberá acreditarse durante el término probatorio del juicio.

${ }^{88}$ Véase nota al pie de página $N^{\circ} 77$.

89 Ídem.
} 
puede decirse, desde el punto de vista del que los tolera, que son aquellos que para él entrañan el ejercicio de un derecho, como es permitirlos o no, y a cuya ejecución no se opone por benevolencia y considerando que no atentan contra la integridad del contenido de su derecho. Desde el punto de vista del tercero, son actos de mera tolerancia los que él realiza sin la intención de ejercitar un derecho propio, sino basándose en la condescendencia del titular del derecho ejercitado" . Más adelante los autores agregan que: "Para calificar un acto como de mera tolerancia o no, es preciso atender al ánimo o voluntad de las dos partes. Habrá un acto de esa naturaleza si el agente, o sea, el que lo ejecuta lo hace sin ánimo de realizar un acto posesorio o de ejercicio de un derecho propio, y si, por su lado, el que soporta el acto lo hace por pura condescendencia" ${ }^{\prime 1}$.

Bajo esta perspectiva, el precarista que lo sea por mera tolerancia del dueño, jamás podría detentar la cosa con ánimo de señor, ya que la mera tolerancia atiende al ánimo o voluntad de ambas partes, lo que necesariamente significa reconocer dominio ajeno, transformándolo irremediablemente en un mero tenedor en los términos del art. $714 \mathrm{CC}$.

Ahora bien, como se adelantó precedentemente, la jurisprudencia no ha sido unánime a la hora de determinar el sentido o alcance de la mera tolerancia. A modo ejemplar, la Corte de Apelaciones de la Serena mediante sentencia de fecha 17 de enero de 2011, dispuso al respecto: “(...) En cuanto al requisito de que la ocupación o tenencia de la cosa se haya producido por mera tolerancia, debe estimarse que se alega que una situación ha acontecido y en atención a ello por tanto debe ser acreditada, siendo la carga de la prueba de la demandante que la alega. Frente a esto surge una interrogante, como es, si la mera tolerancia en la ocupación debe presentarse al momento de interponerse la demanda, o si ella hubo de existir en otro momento. Para dilucidar esto primeramente debe tenerse en cuenta cuál es el significado que a la palabra "tolerancia" concede el diccionario, constatando que es aquél de "Acción y efecto de tolerar", y por tolerar se entiende "Permitir algo que no se tiene por lícito, sin aprobarlo expresamente" (Diccionario de la Lengua Española de la Real Academia Española. Edic. 19a . 1970). En esta situación se estima entonces, que de concluirse que esta tolerancia, o mera tolerancia, o soportar una ocupación que no se estima ajustada a derecho, ha de presentarse al momento de deducirse la demanda, tal requisito quedaría librado al criterio del actor, quien de un momento anterior en que estimara la ocupación lícita y la admitiera de buen grado, pasara a otro momento en que cambiara de modo de pensar estimándola ilícita y que se

90 Alessandri y Somarriva (1974), p. 538.

91 Alessandri y SOMARriva (1974), p. 539. 
encontraba forzado a soportar al ocupante. Admitir esto introduciría un factor de inestabilidad en cuanto al requisito en referencia. A esto se agrega que la situación paralela a la de la mera tolerancia, que es aquella de existir ignorancia respecto de la tenencia de la cosa, lógicamente no podría producirse en ningún caso al momento de deducirse la demanda puesto que necesariamente el demandante debe conocer que hay un ocupante o tenedor en su bien para deducir tal demanda en su contra, lo que hace concluir como indudable que el requisito de ignorar la tenencia se ha debido producir respecto del inicio de la ocupación de un bien por un tercero. Todo esto hace concluir en el sentido de que la mera tolerancia a que alude el artículo 2195 inciso $2^{\circ}$ del Código Civil es el soportar desde su origen la ocupación o tenencia del bien por un tercero, estimando ilícita además tal ocupación ${ }^{\prime \prime 2}$.

Resulta evidente que, bajo esa perspectiva, la mera tolerancia se aborda de forma individual, particularmente a propósito del dueño de la cosa, el que por lo demás estimará ilícita la ocupación. En este orden de ideas, el ánimo de señor o dueño del precarista será compatible con el dueño que tolera la ocupación, ya que no se atiende a la voluntad de las dos partes.

\section{Algunos problemas que pueden plantearse ante la dualidad del precarista}

De acuerdo con lo expuesto en el numeral anterior, el precarista dependiendo de su animus, podrá ser un mero tenedor en los términos del art. 714 CC, o un individuo que sale de la regla de la trilogía jurídica. Ahora bien, cabe preguntarse si este animus al que tanto se alude, es o no un elemento que permita practicar tal diferenciación, y de si existen normas que impidan su aplicación en tales términos. En efecto, existen una serie de normas en el Código Civil que, a primera vista, relegarían al precarista a la mera tenencia, especialmente en los inmuebles adscritos al sistema registral, en que el no reconocimiento de dominio ajeno o la tenencia con ánimo de señor o dueño no constituyen elementos que permitan realizar diferenciación alguna en términos prácticos. En razón de lo anterior, se pasarán a exponer las diversas normas que ponen en duda la posibilidad de concebir al precarista en la forma antes referida.

i. La primera norma a analizar, es el art. 727 CC, que al respecto establece: "La posesión de la cosa mueble no se entiende perdida mientras se halla bajo el poder del poseedor, aunque éste ignore accidentalmente su paradero". Bajo este presupuesto, el simple hecho de perder la cosa, no significa perder su posesión. Frente a lo anterior cabe destacar lo siguiente: A) La acción de precario, pese a

\footnotetext{
${ }_{92}$ Corte de Apelaciones de La Serena, rol № 1015-2010, de 17 de enero de 2011. Considerando Cuarto. Énfasis agregado.
} 
no haber norma que lo impida, no se aplica sobre bienes muebles, en atención a que bastaría que el sujeto pasivo de la acción argumentase que detenta la cosa con ánimo de señor o dueño para enervar la acción. B) La acción de precario tiene por objeto recuperar bienes inmuebles, especialmente aquellos adscritos al sistema registral. C) Entonces, la norma antes descrita, no aplica ni dificulta lo expuesto en el capítulo precedente.

ii. Una segunda norma que podría dificultar la dualidad del precarista, es el art. 2499 CC, que sobre el particular dispone lo siguiente: "La omisión de actos de mera facultad, y la mera tolerancia de actos de que no resulta gravamen, no confieren posesión, ni dan fundamento a prescripción alguna". Respecto a los actos de mera tolerancia, ya se explicó que su significado es de difícil determinación, y que, dependiendo de la postura que se adopte, impedirá o no al precarista detentar la cosa con ánimo de señor o dueño. Respecto a la omisión de actos de mera facultad, a primera vista, impediría al precarista obtener la posesión sobre el inmueble. En efecto, el poseedor inscrito, por el solo hecho de no ejercer actos de mera facultad sobre el inmueble respectivo, no confiere posesión al que lo hace.

Con relación a lo anterior se pueden efectuar los siguientes comentarios: A) La omisión de actos de mera facultad respecto de un inmueble inscrito no impide que otra persona ejerza sobre ella actos posesorios, e inclusive logre inscribirlo a su nombre en el Conservador de Bienes Raíces respectivo, claro ejemplo de ello es el Decreto Ley No 2.695. El problema del argumento recién indicado es que el aludido Decreto Ley se aplica respecto de inmuebles que cumplen con determinadas características, lo que impide su aplicación general. B) Dependiendo del valor que se otorgue a la inscripción conservatoria, se podrá aplicar en mayor o menor medida la limitación que impone el art. 2499 CC. Así, por ejemplo, si se considera la inscripción registral como prueba absoluta de posesión de los inmuebles inscritos, y el precarista comienza a detentar un inmueble inscrito, poco importará el ánimo de señor o dueño que esgrima, ya que la sola inscripción, relacionada con el art. 2499 CC, le impediría obtener la posesión. Ahora bien, lo anterior no obsta que el precarista que detente la cosa sin reconocer dominio ajeno, o con ánimo de señor o dueño, se encuentre alejado de la figura de la mera tenencia. En otras palabras, el hecho de que no pueda adquirir la posesión -inscrita- del inmueble, no impide que su animus lo diferencie del mero tenedor. En efecto, aquí no se defiende la posibilidad de que el precarista mejore su estado sobre la cosa, sino más bien que la imposibilidad de obtener la posesión inscrita no es óbice para utilizar la cosa con ánimo de señor o dueño. Por otra parte, si se adscribe a la teoría de la inscripción-garantía y aquella parte de la doctrina que flexibiliza los requisitos para obtener la posesión irregular de bienes raíces sujetos al sistema registral, y el precarista junto 
con ocupar la cosa con ánimo de señor, ejerce actos posesorios, sería discutible la aplicación del art. 2499 CC, ya que, aunque exista inscripción registral en su contra, ella sólo es una garantía, pero no prueba absoluta de la posesión. En efecto, si se privilegian los actos posesorios, el art. 2499 CC no debiera tener mayor beneficio sobre quien tiene inscrito un bien raíz a su nombre sin ejercer actos posesorios sobre el mismo. En este caso, se considerará poseedor del inmueble al que pruebe serlo en los términos de los artículos 700 y 925 CC. C). De lo anterior se desprende que, si bien los actos de omisión de mera facultad no confieren posesión, ello no impide prima facie que un individuo ocupe la cosa sin reconocer dominio ajeno, e incluso bajo la premisa del Decreto Ley $\mathrm{N}^{\circ} 2.695$ o de conformidad con lo dispuesto en el art. $700 \mathrm{CC}^{93}$, logre obtener la posesión, de esgrimir ánimo de señor o dueño. D) Finalmente, pareciera ser que el sentido de la norma, más que impedir que otro entre en posesión de la cosa, es establecer que la omisión de actos de mera facultad por sí solos no confieren posesión respecto de otra persona.

iii. Una tercera norma que genera dificulta la aplicación de la dualidad del precarista, es el inciso $2^{\circ}$ del art. $728 \mathrm{CC}$, que al respecto dispone lo siguiente: "Mientras subsista la inscripción, el que se apodera de la cosa a que se refiere el título inscrito, no adquiere posesión de ella ni pone fin a la posesión existente". Sin perjuicio de que lo expuesto en este artículo prácticamente impide adquirir la posesión de un bien adscrito al sistema registral sin la competente inscripción, ello no obsta que quien detente una cosa ajena no reconozca dominio ajeno, o manifieste ánimo de señor o dueño. En efecto, cuando se alude al ánimo de señor o dueño no se pretende equipararlo a la figura de la posesión inscrita y a los beneficios ello puede implicar. Principalmente porque la posesión sobre inmuebles inscritos se aleja de los elementos del corpus y animus, relegando su prueba a la mera inscripción registral. Dicho de otra forma, aunque la posesión se defina como la tenencia de una cosa determinada con ánimo de señor o dueño, se debe recordar que, en los inmuebles adscritos al sistema registral, la posesión se prueba de acuerdo con lo dispuesto en los artículos 724 y 728 CC, relegando a segundo plano los elementos del corpus y animus. Así, el inciso $2^{\circ}$ del art. 728 CC impide que el ocupante de un inmueble inscrito gane la posesión en los términos del art. 724 CC, pero no impide que dicha tenencia se haga sin reconocer dominio ajeno, o incluso con ánimo de señor o dueño. Por ello, es perfectamente compatible detentar un inmueble (ajeno) adscrito al sistema registral, sin reconocer dominio ajeno, o bien con ánimo de señor o

${ }_{93}$ Bajo el alero de la teoría inscripción-garantía y de la doctrina que apoya la posesión irregular sin título. 
dueño, sin perjuicio de que esta última hipótesis no lo hará poseedor ${ }^{94}$ en los términos del art. $724 \mathrm{CC}$.

iv. Un cuarto escollo, relacionado directamente con la norma antes señalada, es un pasaje del mensaje (\$21) del Código Civil, que en lo pertinente señala: "la inscripción es la que da la posesión real, efectiva; y mientras ella no se ha cancelado, el que no ha inscrito su título no posee: es un mero tenedor ${ }^{\prime \prime 95}$. Es decir, para Bello, mientras no se disponga de una inscripción, quien detente un inmueble -adscrito al sistema registral- no será más que un mero tenedor, aunque posea un título a su favor. Bajo esta perspectiva, a falta de título, menos aún se podría detentar materialmente un inmueble y adquirir su posesión. De acuerdo con el mensaje, el solo hecho de carecer de inscripción automáticamente trasforma al detentador material en un mero tenedor, y si este último se entiende según lo dispuesto en el art. 714 CC, el animus del precarista entraría en conflicto con la regla de inmutabilidad que establece el art. 716 CC.

Respecto a lo anterior resulta interesante destacar lo siguiente: A) En primer término, pareciera ser que el mensaje contraviene lo dispuesto en el art. 714 CC, norma que regula la mera tenencia estableciendo como elemento característico el reconocimiento de dominio ajeno. B) El mensaje de Bello sobre el particular se encuentra circunscrito en un contexto en que el autor, más que tratar de efectuar una regla de destacarte, explicaba la importancia que tendría la inscripción registral, y su idea de que, en un futuro no muy lejano, la inscripción fuera sinónimo de posesión y propiedad. C) Si bien el mensaje es bastante claro, su texto no solo dificulta la dualidad del precarista, sino que entra en conflicto con la aplicación del Decreto Ley № 2.695 y en general contra cualquier persona que pretenda adquirir el dominio de un bien raíz adscrito al sistema registral, sin inscripción a su nombre, aunque eventualmente pudiera tener el legítimo derecho a ello. D) Por otra parte, en los capítulos anteriores se concluyó que la figura del inciso $2^{\circ}$ del art. 2195 CC es asimilable al comodato precario, en cuyo supuesto, el precarista necesariamente sería un mero tenedor. E) Entonces, el mensaje difícilmente podría cubrir la situación contemplada en el inciso $2^{\circ}$ del art. 2195 CC en la forma que se ha interpretado por la jurisprudencia

${ }^{94}$ Con excepción de lo dispuesto en el Decreto Ley No 2.695. Asimismo, si se aboga por la teoría de la inscripción-garantía, quien ocupe un inmueble con ánimo de señor o dueño, aunque no se encuentre inscrito a su nombre, incluso podría considerarse poseedor irregular y, en su mérito, llegar a adquirir el dominio mediante las reglas de la prescripción adquisitiva extraordinaria, ello, claro está, siguiendo la doctrina que sostiene la posibilidad de ser poseedor irregular sin título.

${ }_{95}$ Misma idea se encuentra recogida en el art. 696 CC: "Los títulos cuya inscripción se prescribe en los artículos anteriores, no darán o transferirán la posesión efectiva del respectivo derecho, mientras la inscripción no se efectúe de la manera que en dichos artículos se ordena; pero esta disposición no regirá sino respecto de los títulos que se confieran después del término señalado en el reglamento antedicho". 
mayoritaria, ya que de acuerdo con la correcta interpretación, el precarista será un mero tenedor en virtud de la asimilación del precario al contrato de comodato precario que efectúa el propio texto de la ley, por lo que es dable sostener que el mensaje únicamente es una declaración de principios a propósito de la importancia de la inscripción conservatoria de los bienes raíces adscritos al sistema registral.

Mediante el análisis antes efectuado, se ha intentado demostrar que, bajo la concepción que se tiene hoy en día del inciso $2^{\circ}$ del art. 2195 CC, no existe impedimento legal efectivo que limite utilizar un inmueble inscrito a nombre de un tercero, sin reconocer dominio ajeno e incluso con ánimo de señor o dueño, haciendo la salvedad de que ello, probablemente ${ }^{96}$, no tendrá mayores implicancias en una eventual adquisición de la posesión inscrita, pero sí permitirá delimitar con mayor precisión la naturaleza jurídica del precarista, a la luz de lo señalado por la jurisprudencia en los últimos treinta años.

\section{La dualidad del precarista y su relación con la teoría de la inscripción-ficción e inscripción-garantía}

Según lo expuesto en las páginas precedentes, se ha señalado que la naturaleza jurídica del precarista -con arreglo a como se concibe hoy en día el inciso $2^{\circ}$ del art. 2195 CC- variará dependiendo del animus con que detente la cosa. Pues bien, a dicho respecto, y de conformidad a lo establecido en el inciso $2^{\circ}$ del art. $714 \mathrm{CC}$, se concluyó que en todos aquellos casos en que el precarista ocupe la cosa reconociendo dominio ajeno, será un mero tenedor. En caso contrario, esto es, cuando el precarista ocupa la cosa sin reconocer dominio ajeno, ya no estaríamos frente a un mero tenedor, sino que, al parecer, ante nuevo estado del individuo frente a una cosa. Asimismo, se indicó que el no reconocer dominio ajeno habilita además la posibilidad de utilizar la cosa con ánimo de señor o dueño.

Sin perjuicio de ello, pareciera ser que el precarista que detenta la cosa con ánimo de hacerla suya, más que un nuevo estado del individuo frente a una cosa, es un poseedor en los términos del art. $700 \mathrm{CC}^{97}$. Es del caso aclarar

\footnotetext{
${ }_{96}$ Ahora bien, nada obsta que el precarista bajo una hipótesis como la planteada en estas páginas, pudiere intentar una demanda reconvencional de prescripción adquisitiva extraordinaria, aduciendo que es poseedor irregular y que se cumplen los requisitos de procedencia de la prescripción, lo que claramente dificultará el éxito de la acción de precario deducida en procedimiento sumario. Es más, con esa sola defensa eventualmente podría enervarse la acción de precario, por considerar el Juez que, al existir controversia sobre el dominio del inmueble, correspondía accionar bajo procedimiento ordinario de lato conocimiento.

97 Importante es determinar que dicha posesión, de ser considerada como tal (ver nota al pie de página № 77), sería irregular. Asimismo, la línea que separa dicha posesión de una clandestina es bastante
} 
que la veracidad de tal afirmación, dependerá según la teoría que se adopte respecto del valor que tiene la inscripción registral, y de las condiciones que se consideren suficientes para adquirir la posesión irregular de bienes raíces sujetos al sistema registral.

Antes de continuar con la explicación de lo enunciado en el párrafo precedente, y sin perjuicio de lo ya señalado en las páginas anteriores respecto a la inscripción-ficción e inscripción-garantía, resulta necesario explicar las dos grandes teorías que existen respecto del valor que se otorga a la inscripción de los inmuebles adscritos al sistema registral, cuestión que, como se verá, resultará fundamental a la hora de calificar la naturaleza jurídica del precarista que detenta un bien raíz -inscrito a nombre de otra persona- sin reconocer dominio ajeno, y, en especial, con ánimo de señor o dueño.

Una parte importante de la doctrina ${ }^{98}$ adhiere a la teoría denominada inscripción-ficción, la que a grandes rasgos postula que la inscripción registral es símbolo absoluto de posesión, una ficción que asimila al poseedor inscrito como si tuviera la tenencia de un bien raíz con ánimo de señor o dueño, aunque ello no sea así. Su principal argumento se basa en el art. 724 CC, el que señala: "Si la cosa es de aquellas cuya tradición deba hacerse por inscripción en el Registro del Conservador, nadie podrá adquirir la posesión de ella sino por este medio". Bajo esta postura, la tenencia de un bien raíz a manos de un tercero ajeno a la inscripción, jamás lo convertirá en poseedor, aunque tenga la cosa con ánimo de señor o dueño.

Pues bien, éste sería justamente el caso de un precarista que detenta la cosa sin reconocer dominio ajeno o con ánimo de señor o dueño que, como se ha sostenido, no es mero tenedor en los términos del art. $714 \mathrm{CC}^{99}$, y tampoco es poseedor en los términos que disponen los artículos 724 y 728 CC. Así las cosas, bajo el alero de la teoría de la inscripción-ficción (que impera en la actualidad), es dable sostener que el precarista que lo sea en los términos recién descritos se

tenue, sin perjuicio de que para que se verifique esta última no basta detentar una cosa ajena, sino que, además, ocultar dicha ocupación del verdadero dueño, cuestión que habría que determinar caso a caso, más allá de que parte de la doctrina señala que la clandestinidad difícilmente se podría dar en bienes raíces. Con todo, e incluso en aquellos casos en que la tenencia precaria se haya ejercido ocultándola del verdadero dueño, a lo menos desde el momento en que este último ejerza alguna acción ante los Tribunales Ordinarios de Justicia con el objeto de obtener la restitución del inmueble, como podría ser una demanda de precario o la acción del art. 915 CC, dicha posesión dejaría de ser clandestina, y el demandado podría defenderse en juicio, con mayor o menor éxito, como poseedor irregular.

98 Véase: Trucco (1910), pp. 131 y ss.; LIRA (1927) y LaGos (1926), pp. 117 y ss.

99 Ello atendido que no reconoce dominio ajeno. 
encuentra fuera de las figuras clásicas del dominio, posesión y mera tenencia ${ }^{100}$, configurándose un nuevo estado del individuo sobre la cosa. En efecto, bajo tales presupuestos, en la hipótesis de tenencia sin reconocimiento de dominio ajeno (pero sin esgrimir ánimo de señor o dueño), el precarista se aleja de las hipótesis de dominio, posesión y mera tenencia, mientras que en la hipótesis en que se utiliza la cosa con ánimo de señor o dueño, estamos frente a una situación de hecho que, si bien comparte los elementos de la posesión (animus et corpus), se aleja del cumplimiento de los requisitos para obtener la posesión de bienes adscritos al sistema registral en razón de lo dispuesto en los artículos 724 y 728 CC. En caso de que se conciba al precarista en los términos antes descritos, si bien no genera per se consecuencias directas a favor o en contra del precarista, no se debe perder de vista que todo precarista que se encuentre en una situación que no signifique la mera tenencia ${ }^{101}$ del bien raíz, en los términos del art. $714 \mathrm{CC}$, supone un potencial peligro para el legítimo dueño de la cosa. En efecto, y sin perjuicio de que en la actualidad prima una postura que privilegia la inscripción registral, siempre existe la contingencia de que en un juicio se termine adoptando una postura que favorezca la tenencia material del bien por sobre la inscripción registral.

\footnotetext{
100 La Corte Suprema, en los autos rol 30038-2014, en sentencia de fecha 10 de diciembre de 2015, señaló respecto al precarista, lo siguiente: " $8^{\circ}$. La institución especial que define el inciso segundo del artículo 2195 del código de Bello, adquiere sentido en el derecho chileno y en el contexto normativo de esa compilación, en la medida que se trata de una situación puramente fáctica, que no puede asociarse a ninguna clase de fuente de derecho en la que el precarista pueda ampararse; simplemente él está en lo ajeno, careciendo de la condición de dueño, de poseedor, incluso de tenedor y mero tenedor" (énfasis agregado). La sentencia antes señalada, si bien mantiene la postura predominante respecto a la naturaleza jurídica del precario, innova y se refiere al precarista, señalando que éste, no detenta la calidad de dueño, poseedor, tenedor o mero tenedor. Si bien, en esta sentencia se concuerda con el postulado de estas páginas respecto de que el precarista vendría a constituir un nuevo estado del individuo frente a una cosa, el fundamento para llegar a dicha conclusión no es el mismo. En efecto, la sentencia reconoce al precarista como una figura distinta, siguiendo probablemente su concepción del Derecho romano primitivo, sin interesar si el precarista reconoce o no dominio ajeno o bien suponiendo que dicha calidad supone el reconocimiento de dominio ajeno. Mismo criterio adoptó la Corte Suprema, en los autos rol 37705-2015, en sentencia de fecha 31 de enero de 2017. Es del caso destacar que las sentencias recién citadas se alejan de la trilogía jurídica que reconoce nuestro Código Civil, y con base en su postulado, es posible concluir que se reconoce que una persona frente a una cosa puede revestir las calidades de dueño, poseedor, mero tenedor y precarista. A lo anterior, se puede agregar el denominado "poseedor material" -de entenderse como un presupuesto fáctico distinto al descrito en el inciso $2^{\circ}$ del art. 2195 CC- que menciona alguna jurisprudencia, y todas aquellas situaciones intermedias que no terminan de cuadrar en la posesión y mera tenencia, como podría ser el injusto detentador.

101 En el entendido de que la regla $3^{\text {a }}$ del art. 2510 CC no tiene una aplicación real en la actualidad, siempre que se acuerde que dicha norma es una regla excepcional que permite al mero tenedor adquirir por prescripción adquisitiva extraordinaria, y no como una regla que muta la mera tenencia en posesión.
} 
Ahora bien, y en directa relación con la prevención expuesta precedentemente, la situación podría cambiar si se radicaliza el alcance de la teoría inscripción-garantía. Los autores que sostienen esta teoría ${ }^{102}$, plantean básicamente: "(...) que la calidad de inmueble de la cosa no altera la naturaleza jurídica denominado posesión y que, conforme a la definición del art. 700, consiste en la tenencia de una cosa determinada con ánimo de señor o dueño (...). No se concibe posesión de un inmueble sin la concurrencia de esos requisitos primordiales: corpus et animus; de suerte que la inscripción conservatoria no puede tener otros alcances que los de favorecer y proteger ese estado de hecho que no puede ser reemplazado por ninguna ficción (... $)^{\prime 103}$. Bajo esta postura, el precarista que ocupa una cosa sin reconocer dominio ajeno, continúa encontrándose en una situación que escapa a las figuras clásicas del dominio, posesión y mera tenencia, pero, cuando esgrima ánimo de señor y dueño sobre un inmueble inscrito a nombre de un tercero, el precarista, se podría llegar a considerar poseedor irregular ${ }^{104}$ del mismo, en razón de privilegiarse el corpus y el animus por sobre la inscripción registral. Con todo, es importante señalar que, aunque los adeptos a esta teoría resaltan la importancia del corpus y animus del art. $700 \mathrm{CC}$ a efectos de acreditar la posesión, en el caso de inmuebles adscritos al sistema registral, destacan la regla del inciso $2^{\circ}$ del art. 728 CC, y de cómo actos físicos de apoderamiento no podrían generar efecto alguno frente al poseedor inscrito. Ahora bien, de todas formas, la situación antes descrita podría ser cuidado, ya que, en caso de extremar la aplicación de esta teoría, relacionándola con lo dispuesto en la $1^{\text {a }}$ regla del art. 2510 CC, frente a una demanda de precario, y siempre que se cumplan los presupuestos objetivos de la prescripción adquisitiva extraordinaria, el demandado podría discutir el dominio del bien, e incluso, en una hipótesis poco probable, adquirir el dominio del bien raíz. La situación antes descrita se vuelve más plausible todavía, en aquellos casos en que el precarista justifica su tenencia en un título traslaticio emanado de un tercero distinto al dueño (siguiendo la jurisprudencia que considera procedente la acción de precario frente a esta situación, en cuyo caso el demandado adquiere la calidad de "precarista"). Así las cosas, se denota que, frente a una misma situación de hecho, el precarista podría tener una calidad distinta, cuestión que dependerá básicamente del valor que se le otorgue a la inscripción y de las condiciones que se consideren suficientes para adquirir la posesión irregular de bienes raíces adscritos al sistema registral.

102 Véase, por ejemplo: URrUtia (1934), p. 5 y DáVILA (1928).

103 Pescio (1978), pp. 360-361.

104 Véase nota al pie de página $N^{\circ} 77$. 
Todo lo anterior, en razón de la concepción que se tiene hoy en día del inciso $2^{\circ}$ del art. 2195 CC, ya que, si dicha situación de hecho se asimilase en sus efectos al comodato precario, tal como señala el inciso $2^{\circ}$ al utilizar el adverbio "también", necesariamente el precarista sería mero tenedor, ya no por una regla de descarte, lo que por lo demás se encuentra acorde a la regulación que establece el Código Civil respecto al dominio, posesión y mera tenencia. Es justamente esta trilogía jurídica, lo que probablemente ha motivado a algunos autore $^{105}$ a calificar al precarista como mero tenedor. El problema es que la situación descrita en el inciso $2^{\circ}$ del art. 2195 CC, concebida como una situación de hecho no asimilable al comodato precario, es ajena a nuestra legislación, y no cuadra con la trilogía jurídica que celosamente resguarda nuestro Código Civil.

Por lo mismo, la única forma de mantener intacta la trilogía jurídica es comprender al precario como una situación de hecho especial, asimilable al comodato precario, en cuyo caso el precarista ya no podría no reconocer dominio ajeno ni menos detentar una cosa ajena con ánimo de señor o dueño, ya que el comodato precario es un contrato real en que se reconoce dominio ajeno, transformando irremediablemente al precarista en un mero tenedor en los términos del art. 714 CC.

\section{Conclusiones}

Mediante el presente artículo, se ha intentado dejar en evidencia que la institución del precario, pese a contar con un desarrollo importante desde el punto de vista doctrinario y jurisprudencial, arremolina a su respecto una serie de interrogantes que son de difícil solución, especialmente porque la situación de hecho descrita en el inciso $2^{\circ}$ del art. 2195 CC no se considera asimilable al contrato de comodato precario, otorgándole una naturaleza especial que, en los términos desarrollados por la jurisprudencia actual, y dependiendo del animus que esgrima el precarista, se aleja del dominio, posesión y mera tenencia.

En efecto, de una interpretación armónica de los incisos $1^{\circ}$ y $2^{\circ}$ del art. 2195 CC se llega a la conclusión de que el inciso $2^{\circ}$, pese a regular una situación fáctica especial, debe asimilarse a la figura del comodato precario. En este sentido, la naturaleza jurídica del precario sería la de una situación de hecho especial asimilable al contrato de comodato precario, hipótesis en la cual la naturaleza jurídica del precarista correspondería a la de un mero tenedor en los términos del art. 714 CC, sin necesidad de forzar su aplicación recurriendo a una regla de descarte cuya aplicación es a lo menos discutible, en razón de la exigencia de reconocimiento de dominio ajeno que supone la mera tenencia.

105 Barcia (2010), p. 59; Barrientos (2005), p. 230. 
Ahora bien, al concebir al precario como una situación de hecho no asimilable al contrato de comodato precario, se dificulta la calificación jurídica del precarista, ya que para ser considerado mero tenedor en los términos del inciso $2^{\circ}$ del art. $714 \mathrm{CC}$ se requiere reconocer el dominio ajeno, y si la figura descrita en el inciso $2^{\circ}$ del art. 2195 CC no se considera asimilable al comodato precario, el precarista podría, (i) detentar la cosa reconociendo dominio ajeno, en cuyo caso será efectivamente un mero tenedor, o bien, (ii) ocuparla sin reconocer dominio ajeno, último supuesto en que incluso podría esgrimir ánimo de señor o dueño. Conforme a la última de las hipótesis antes mencionadas, se expusieron los principales artículos del Código Civil chileno que podrían dificultar la posibilidad de entender que el precarista puede circunscribir a su respecto una situación diversa a la mera tenencia, normas que analizadas en su conjunto no logran -a juicio el autor- descartar de forma absoluta y sin discusión la posibilidad de comprender al precarista en los términos expuestos a lo largo de estas páginas.

Es importante destacar que esta dualidad del precarista encuentra su fundamento en el sentido o alcance que nuestros tribunales de justicia han atribuido al inciso $2^{\circ}$ del art. 2195 CC. En otras palabras, de seguirse la doctrina que equipara al precario con el contrato de comodato precario, no podría sostenerse una dualidad en el precarista, en cuyo caso la naturaleza jurídica del precarista se relega necesariamente a la de un mero tenedor. En efecto, en estas páginas no se pretende postular como correcta la teoría que postula una dualidad del precarista, sino más bien demostrar que de acuerdo a la interpretación que impera actualmente respecto del sentido o alcance del inciso $2^{\circ}$ del art. 2195 CC, relacionado con el tenor literal del inciso $2^{\circ}$ del art. 714 CC, es perfectamente posible llegar a una conclusión como la anotada precedentemente.

En razón de lo anterior, y atendida la aplicación actual del inciso $2^{\circ}$ del art. 2195 CC, resulta necesario precisar la calificación jurídica del precarista, demostrándose que bajo dicha concepción puede presentar una naturaleza jurídica de difícil determinación, que incluso puede entenderse como un nuevo estado del individuo frente a una cosa, ya que puede detentar la cosa sin reconocer dominio ajeno y a la vez sin pretenderse dueño, y, en la hipótesis de ocupar la cosa con ánimo de señor o dueño, aunque se contemplen las características propias de la posesión (corpus y animus), se aleja de los presupuestos para adquirir la posesión de bienes raíces adscritos al sistema registral. Y es que justamente, al concebir al precario como una situación de hecho especial ajena al comodato precario, se facilita la posibilidad de acercarse a la posesión irregular ${ }^{106}$, y paradójicamente alejarse de la mera tenencia en los términos que regula el art. 714 CC.

106 Véase nota al pie de página № 77. 
Lo expuesto en estas páginas no sólo es complejo en términos teóricos, sino también en términos prácticos, pudiendo generarse situaciones de difícil aceptación, como podría ser el caso de un precarista que, utilizando una cosa con ánimo de dueño, mejore su estado a poseedor irregular ${ }^{107}$, cuestión que de por sí resulta cuestionable, teniendo en especial consideración que el precarista -por regla general- se considera la situación más desfavorable en que puede encontrarse un individuo. Dicho de otra forma, si no resulta posible mudar la mera tenencia en posesión conforme a las reglas de inmutabilidad que contempla el art. 716 CC, ies dable sostener que el precarista -en la hipótesis antes descrita-, pudiera terminar como poseedor irregular de la cosa?

Sin perjuicio de éste y otros interrogantes que puedan surgir a propósito de la posibilidad de concebir al precarista en la forma antes referida, mientras se mantenga la interpretación actual de parte de nuestros tribunales de justicia, la dualidad que puede revestir el precarista se fundamenta en el propio inciso $2^{\circ}$ del art. $2195 \mathrm{CC}$, relacionado con el inciso $2^{\circ}$ del art. 714 del referido cuerpo legal, que permite clasificar al precarista dependiendo del animus con que detente la cosa, como mero tenedor, o como una figura compleja que bajo ciertas hipótesis se aleja de los estados tradicionales en que un individuo puede encontrarse frente a una cosa.

Ahora bien, para solucionar esta dificultad bastaría que los tribunales de justicia, pese a reconocer en el inciso $2^{\circ}$ del art. 2195 CC una situación fáctica especial, la asimilaran en sus efectos a la figura contractual regulada en su inciso $1^{\circ}$, lo que permitiría calificar sin mayor dificultad ni discusión al precarista como un mero tenedor, acorde a la exigencia que contempla el art. 714 CC, manteniendo intacta la denominada trilogía jurídica que regula nuestro Código Civil. Lo anterior, dada la amplia gama de situaciones de hecho que pueden circunscribirse en la figura descrita en el inciso $2^{\circ}$ del art. 2195 CC, permitiría además encasillar a aquellas situaciones intermedias de difícil determinación en la figura de la mera tenencia, impidiendo que con un eventual cambio de criterio que pudiere darse en tribunales respecto del valor de la inscripción registral se alcanzare a afectar el derecho de propiedad del legítimo dueño de la cosa.

\section{BiBLIOGRAFÍA CITADA}

Alessandri Rodríguez, Arturo y Somarriva Undurraga, Manuel (1974): Los Bienes y Los Derechos Reales. Explicaciones de clases redactadas, ampliadas y puestas al día por Antonio Vodanovic H. (Santiago, Editorial Nascimento, $3^{\text {a }}$ edición), p. 1.030.

107 Ídem. 
Álvarez GonzÁlez, Humberto (1926): La inscripción no es requisito, garantía, ni prueba de la posesión de los bienes raíces, Memoria de Prueba Universidad de Chile (Santiago, Imprenta y Librería «Artes y Letras»), p. 216.

Argüello, Luis (1998): Manual de Derecho Romano - Historia e Instituciones (Buenos Aires, Editorial Astrea de Alfredo y Ricardo Depalma, $3^{\text {a }}$ edición corregida), p. 589.

Atria Lemaitre, Fernando (2005): "Derechos Reales", en: Revista de Derecho de la Universidad Adolfo Ibáñez, (No 2), pp. 29-97.

Barcia Lehmann, Rodrigo (2007): Lecciones de Derecho Civil Chileno. De las Fuentes de las Obligaciones, Manuales Jurídicos No 117 (Santiago, Editorial Jurídica de Chile), Tomo II, p. 294.

Barcia Lehmann, Rodrigo (2010): Lecciones de Derecho Civil Chileno. De los Bienes, Manuales Jurídicos No 119 (Santiago, Editorial Jurídica de Chile), Tomo IV, p. 214.

Barrientos Grandón, Javier (2005): “De los Bienes y de su Dominio, Posesión, Uso y Goce", en: Revista Chilena de Derecho Privado, (No 4), pp. 221-249.

Barrientos Grandón, Javier (2016): El Código Civil. Su Jurisprudencia e Historia,(Santiago, Editorial Thomson Reuters), Tomo II, p. 1.271.

Belmar C., Eduardo (2010): "Sobre la utilidad de la posesión viciosa", en: Doctrinas Esenciales Derecho Civil. Bienes (Santiago, Editoriales Jurídica de Chile, Punto Lex y Thomson Reuters), pp. 579-589.

Bonfante, Pietro (1944): Historia del Derecho Romano (Madrid, Traducción de José Santa Cruz Teijeiro, Editorial Revista de Derecho Privado), Tomo I, p. 600.

CANo Moriano, Guadalupe (1999): Estudio sobre la figura del precario (Madrid, Edersa), p. 260.

Castillejo, José (2004): Historia del Derecho Romano: política, doctrinas, legislación y administración (Madrid, Editorial Dykinson), p. 527.

Claro Solar, Luis (2013): Explicaciones de Derecho Civil Chileno y Comparado, De los Bienes,(Santiago, Editorial Jurídica de Chile), Vol. III, Tomo VII, p. 537.

Colin, Ambroise y CAPITANT, H. (1923): Cours Élémentaire de Droit Civil Francais, Tome Premier, conforme au programme de premiere annee (Paris, Librairie Dalloz, Quatrieme Edition), p. 1.043.

DÁvILA IZQUIERDo, Oscar (1928): Posesión y Prescripción de Inmuebles Inscritos, (Santiago, Imprenta Cervantes), p. 139.

Domínguez Águila, Ramón (1995): "Precario y Comodato Precario. Reglas Aplicables. Suspensión de Lanzamiento", en: Revista de Derecho Universidad de Concepción, (№ 198), pp. 193-196. 
Domínguez Águila, Ramón (2005): “Código Civil y Jurisprudencia: instituciones jurisprudenciales con base en la letra del Código", en: Martinic, María Dora, y Tapia, Mauricio (dir.), Sesquicentenario del Código Civil de Andrés Bello, pasado, presente y futuro de la codificación (Santiago, LexisNexis), Tomo I, pp. 331-357.

Figueroa Yáñez, Gonzalo (1998): Repertorio de Legislación y Jurisprudencia Chilenas, Código Civil y Leyes Complementarias (Santiago, Editorial Jurídica de Chile, $3^{\text {a }}$ edición), Tomo IX, p. 225.

Guzmán Brito, Alejandro (1996): Derecho Privado Romano, Tomo I. (Santiago, Editorial Jurídica de Chile), p. 802.

Halabí Riffo, Fuad y Saffirio Suárez, Carlos (1996): La Acción de Precario ante la Doctrina y la Jurisprudencia (Santiago, Editorial Jurídica Conosur), p. 117.

LAGos Lagos, Moisés (1926): “Consideraciones sobre la posesión y, especialmente, sobre la de los bienes raíces", en: Revista de Derecho y Jurisprudencia, Tomo XXIII, primera parte, pp. 116-146.

Larroucau, Jorge (2015): "Acciones reales y estándares de prueba", en: Revista lus et Praxis, (Vol. 21, № 2), pp. 109-160.

Larroucau, Jorge y Rostión, Ignacio (2013): "Del juicio precario", en Barcia, Rodrigo, (Edit.), Fundamentos de derechos reales en el derecho chileno (Santiago, LegalPublishing - Thomson Reuters), pp. 37-105.

LatHrop Gómez, Fabiola (2011): "Procedencia de la acción meramente declarativa de dominio en el derecho chileno", en: Revista lus et Praxis, (Vol. 17, No 2), pp. 3-23.

LeCARos SÁnchez, José (2008): "Algunas consideraciones sobre el precario en la jurisprudencia", en: Revista Ars Boni et Aequi, (Vol. 4), pp. 91-99.

LIRA LIRA, Alejandro (1927): El Régimen de la Inscripción Conservatoria (Santiago, Alegato, Imp. Talleres de Prisiones).

Moreno Mochol, Miguel (1951): El Precario (Barcelona, Bosch, Casa Editorial), p. 528.

Morineau Iduarte, Marta e Iglesias González, Román (1998): Derecho Romano (México D.F, Oxford University Press, Oxford México, 4ª edición), p. 296.

Orrego Acuña, Juan (2015): Los Contratos Reales. Legislación, doctrina y jurisprudencia (Santiago, Ediciones Universidad Finis Terrae), p. 896.

Peñallillo Arévalo, Daniel (2006): Los Bienes. La Propiedad y otros Derechos Reales (Santiago, Editorial Jurídica de Chile), p. 604.

Pérez PeÑa, María (2014): "La protección del dueño ante quien retiene indebidamente un bien. Análisis jurisprudencial del artículo 915 del Código de 
Bello", en: Revista de Derecho, Universidad Católica del Norte, (Año 21, $\mathrm{N}^{\circ} 1$ ), pp. 387-421.

Pescio Vargas, Victorio (1978): Manual de Derecho Civil - De la copropiedad, de la propiedad horizontal y de la posesión (Santiago, Editorial Jurídica de Chile), Tomo IV, p. 555.

Petit, Eugene (2007): Tratado elemental de Derecho Romano, traducido de la novena edición francesa por D. José Ferrández González (México, Editorial Porrúa), p. 717.

PLANIOL, Marcel y RIPERT, Georges (1997): Traite Élémentaire de Droit Civile, Biblioteca Clásicos del Derecho (México, Distribuidor Harla S.A.), Tomo VIII, p. 1.563.

Ramos Pascual, Graciela (1982): Comodato Precario y Precario, Memoria de Prueba, Concepción.

Ramos Pazos, René (1986): "Del Precario", en: Revista de Derecho Universidad de Concepción, ( $\left.\mathrm{N}^{\circ} 180\right)$, pp. 7-19.

Rodríguez Grez, Pablo (1994): De las Posesiones Inútiles en la Legislación Chilena (Santiago, Editorial Jurídica de Chile, 2a edición), p. 209.

RostıÓN, Ignacio (2014): El precario en la jurisprudencia chilena (1996 a 2013), (Santiago, LegalPublishing - Thomson Reuters), p. 216.

Samper Polo, Francisco (2007): Derecho Romano (Santiago, Ediciones Universidad Católica de Chile, $2^{\text {a }}$ edición), p. 421.

Selman Nahum, Arturo (2011): "Artículo 915 del Código Civil: una solución jurisprudencial a la limitación de las acciones tradicionales", en: Revista lus et Praxis, (Vol. 17, № 1), pp. 57-80.

TAPIA RodríGuez, Mauricio (2015): "Reivindicación contra el injusto detentador. El controvertido y enigmático artículo 915 del Código Civil.", en: Barría, Manuel; Caprile, Bruno; Diez, José Luis; Domínguez, Carmen; Pizarro, Carlos y Tapia, Mauricio (Edit.), Estudios de Derecho Privado. Homenaje al Profesor Ramón Domínguez Águila (Santiago, Thomson Reuters), pp. 405-422.

Trucco, Humberto (1910): "Teoría de la posesión inscrita, dentro del Código Civil chileno", en: Revista de Derecho y Jurisprudencia, (Tomo VII, primera parte), pp. 131-150.

URRUTIA, Leopoldo (1934): "Vulgarización sobre la posesión ante el Código Civil chileno", en: Revista de Derecho y Jurisprudencia, (Tomo XXXI, primera parte), pp. 5-12.

Vega Aravena, Gissela (2002): El comodato precario y el precario ante la jurisprudencia, (Memoria de Prueba, Universidad de Talca), p. 153. 


\section{NORMAS CITADAS}

Código Civil de la República de Chile (2008) (Santiago, Editorial Jurídica de Chile, 18 a edición): artículos 19, 590, 606, 696, 700, 703, 708, 714, 716, 727, 728, 915, 925, 2194, 2195, 2499, 2510.

Decreto Ley No 2.695 (21/07/1979), fija normas para regularizar la posesión de la pequeña propiedad raíz y para la constitución del dominio sobre ella.

Código Civil de Francia, artículos 2266, 2269.

Código Civil de España, artículo 1750.

Código Civil de Italia, artículo 1810.

Código Civil de Portugal, artículo 1137.

Código Civil de Alemania, \$604, $3^{\circ}$.

Código Civil Federal de México, artículo 2511.

Código Civil de Argentina, artículo 2285 (Código actualmente derogado).

Código Civil de Colombia, artículo 2220.

Código Civil de Ecuador, artículo 2098.

El Digesto, a doble texto traducido al castellano del latín, publicado por los hermanos Kriegel, Hermann y Osenbrüggen, Jaime Molinas, Editor - Consejo de Ciento, Barcelona, Tomos I al III, (1889 a 1897).

Las Siete Partidas de Alfonso X el Sabio.

\section{JURISPRUDENCIA CITADA}

Agroturística Estero Cobulto limitada con Klumpp Baumert, María y otros (2013): Corte Suprema 4 de julio de 2013 (acción de precario) en: www.poderjudicial.cl.

Albino Mendoza, Javier con Espinoza Gallardo, Francis (2015): Corte Suprema 10 de diciembre de 2015 (acción de precario) en: www.poderjudicial.cl.

Aliaga Cabeza, luz y otros con Junta de Vecinos № 3 Novena Agrupación Santiago (2017): Corte Suprema 4 de abril de 2017 (acción de precario) en: www. poderjudicial.cl.

Andina Exportadora S.A.C. con Humberto Yáñez, Duamel (2016): Corte Suprema 18 de agosto de 2016 (acción de precario) en: www.poderjudicial.cl.

Astorga Garcés, Jorge con Arratia Díaz, Alejandra (2015): Corte de Apelaciones de Santiago 29 de mayo de 2015 (acción de precario) en: www.poderjudicial.cl.

Baeza Guíñez, Carlos con Fernández Aburto, José (2015): Corte Suprema 22 de septiembre de 2015 (acción de precario) en: www.poderjudicial.cl. 
Banco Bilbao Vizcaya Argentaria Chile. S.A. con Gaete Quezada, María Cristina (2010): Corte Suprema 19 de octubre de 2010 (acción de precario) en: www.poderjudicial.cl.

Banco Falabella con Heresmann Fuentes, Lidia del Carmen (2015): Corte de Apelaciones de Santiago 16 de octubre de 2015 (acción de precario) en: www.poderjudicial.cl.

Barahona Sotelo, Jorge con Díaz Horzella, Daniela (2016): Corte Suprema 19 de octubre de 2016 (acción de precario) en: www.poderjudicial.cl.

Bartolo Choque, luciano con Araya Maldonado, Patricia del C. (2006): Corte Suprema 22 de mayo de 2006 (acción de precario) en: www.poderjudicial.cl.

Biewer Piwonka, Gabriela con Stange Rosmarie y otros (2011): Corte Suprema 7 de julio de 2011 (acción de precario) en: www.poderjudicial.cl.

Canedo Laymen, Jorge Alejandro con Constructora Fides Limitada (2014): Corte de Apelaciones de Iquique 6 de mayo de 2014 (acción de precario) en: www.poderjudicial.cl.

Cazaux Torres, Iris con Ladrón de Guevara, María (2015): Corte Suprema 29 de octubre de 2015 (acción de precario) en: www.poderjudicial.cl.

Comisión Administradora de Comunidad Cuesta La Arena con Guerrero (2015): Corte de Apelaciones de Copiapó 18 de diciembre de 2015 (acción de precario) en: www.poderjudicial.cl.

Coppa Carrasco, Cecilia y otra con Contreras Coppa, Sandra Tatiana (2017): Corte de Apelaciones de Santiago 30 de junio de 2017 (acción de precario) en: www.poderjudicial.cl.

Cordero Molina, María con Olguín Hernández, Juan (2017): Corte Suprema 31 de enero de 2017 (acción de precario) en: www.poderjudicial.cl.

Cruz Venegas, luis con Pacheco lobos, Aurora (2016): Corte Suprema 18 de mayo de 2016 (acción de precario) en: www.poderjudicial.cl.

Díaz Oyarzo, José Enrique con Díaz Lemus, Feliciano (2002): Corte de Apelaciones de Puerto Montt 15 de abril de 2002 (acción de precario) en: Thomson Reuters - WestLaw Cita Online: CL/JUR/3569/2003.

Espinoza Espinoza, Héctor con Espinoza Toro, Pamela (2016): Corte Suprema 29 de marzo de 2016 (acción de precario) en: www.poderjudicial.cl.

Fernández Cortés, Gabriel con Ochoa Esparza, Paula (2017): Corte Suprema 28 de junio de 2017 (acción de precario) en: www.poderjudicial.cl.

Fisco de Chile con Ortega Sepúlveda, Pedro (2016): Corte Suprema 8 de marzo de 2016 (acción de precario) en: www.poderjudicial.cl. 
Galarce Chamorro, Jeanette Paola con Riquelme Charnock, Jocelyn Elizabeth (2016): Corte de Apelaciones de Santiago 26 de abril de 2016 (acción de precario) en: www.poderjudicial.cl.

Gallegos Naipayan, Juan Mauricio, Rodolfo Catalan Vergara con Labra Velasquez, Manuel S. (2012): Corte Suprema 4 de abril de 2012 (acción reivindicatoria) en: www.poderjudicial.cl.

García Contreras, Paola con Sepúlveda Contreras, Jorge (2017): Corte Suprema 10 de abril de 2017 (acción de precario) en: www.poderjudicial.cl.

Guzmán Fuenzalida, Marcia con Leyton Espinoza, Antonio (2017): Corte Suprema 11 de abril de 2017 (comodato precario) en: www.poderjudicial.cl.

Hernández Andrade, Diego Alberto con Morales Roa, Silvia del Carmen (2017): Corte Suprema 30 de enero de 2017 (acción de precario) en: www.poderjudicial.cl.

Hernández Sepúlveda, Marilinda con Durán Toro, Ana (2007): Corte Suprema 8 de agosto de 2007 (acción de precario) en: www.poderjudicial.cl.

Herrera Peralta, Domingo con Valdebenito Sepúlveda, Rigoberto (1986): Corte de Apelaciones San Miguel 27 de noviembre de 1986 (acción de comodato precario) en: Thomson Reuters - WestLaw Cita Online: CL/JUR/268/1986.

Hurtado Bugueño, Haroldo con lazcano Hormaechea, Macarena (2013): Corte Suprema 9 de enero de 2013 (acción de precario) en: www.poderjudicial.cl.

I. Inversiones Limitada con Vega Cañete, Raúl y otros (2014): Corte Suprema 30 de septiembre de 2014 (acción de precario) en: www.poderjudicial.cl.

inmobiliaria Agrícola e Inversiones Río Grande S.A. con I. Municipalidad de San José De LA MARIQUina (2016): Corte Suprema 20 de julio de 2016 (acción de precario) en: www.poderjudicial.cl.

Inmobiliaria Geosal S.A. con Valenzuela Vallejos (Rodrigo Andrés) (2015): Corte Suprema 1 de julio de 2015 (acción de precario) en: www.poderjudicial.cl.

Inmobiliaria Integral Limitada con Basualto JIlberto, Bartolomé (2015): Corte de Apelaciones de Valparaíso 23 de junio de 2015 (acción de precario) en: www.poderjudicial.cl.

Inmobiliaria Vicuña Limitada con Lara Minchel, Alejandro Del Carmen (2011): Corte de Apelaciones de La Serena 17 de enero de 2011 (acción de precario) en: www.poderjudicial.cl.

Inversiones Autopro Limitada con labrín Maza Segundo Javier (2014): Corte Suprema 2 de octubre de 2014 (acción de precario) en: www.poderjudicial. cl. 
Johann Brandner y Compañía Limitada con Cifuentes Rojas, Paola (2016): Corte Suprema 30 de marzo de 2016 (acción de precario) en: www.poderjudicial. cl.

Lagos Pezoa, Amada con Tapia Urra, Arnaldo (2015): Corte Suprema 27 de mayo de 2015 (acción de comodato precario) en: www.poderjudicial.cl.

Lagunas Tapia, Héctor con Peña Cuadra, Ulises (2007): Corte Suprema 12 de noviembre de 2007 (acción de precario) en: www.poderjudicial.cl.

Lara Kiefer, Ilse Editt con Lavoz Gallardo, María (2009): Corte Suprema 12 de noviembre de 2009 (acción de precario) en: www.poderjudicial.cl.

López Estay, Ramón con Briones Olmedo, Eliana (2011): Corte de Apelaciones de Valparaíso 28 de marzo de 2011 (acción de comodato precario) en: www. poderjudicial.cl.

Lupayante Salinas, Antonio con Valenzuela Thielemann, Ximena (2017): Corte de Apelaciones de Santiago 13 de abril de 2017 (acción de precario) en: www. poderjudicial.cl.

Martínez Salas, Rebeca con Irribarra Martínez, Edesia (2017): Corte de Apelaciones de Concepción 16 de junio de 2017 (acción de precario) en: www.poderjudicial.cl.

Massone Péndola, Mafalda y otro con Rojas Crisanto, Julio (2016): Corte Suprema 18 de mayo de 2016 (acción de precario) en: www.poderjudicial.cl.

Mazuelos Quiguallo, Eloísa y otro con Fisco de Chile (2015): Corte Suprema 16 de noviembre de 2015 (acción de precario) en: www.poderjudicial.cl.

Mera Fernández, Teresa con Quinillao, Javier (2008): Corte de Apelaciones de Valdivia 4 de marzo de 2008 (interdicto posesorio) en: www.poderjudicial.cl.

NASer, Jorge con Belfus Boris (1976): Corte Suprema 21 de diciembre de 1976 (acción de comodato precario) en: Fallos del Mes, 1976, № 217, páginas 297-300.

Ojeda Kokisch, Luis Heberto con Dirce Duque, Katty (2000): Corte de Apelaciones de Valparaíso 12 de septiembre de 2000 (acción de precario) en: Thomson Reuters - WestLaw Cita Online: CL/JUR/4700/2000.

Olea García, Iván con Rubio Saldaña, Isaías (2016): Corte Suprema 8 de agosto de 2016 (acción de precario) en: www.poderjudicial.cl.

Ormazábal Sanhueza, Ricardo con Velásquez Muñoz, José y otro (2017): Corte Suprema 19 de enero de 2017 (acción de precario) en: www.poderjudicial.cl.

Porcile Espiñeira, Anita y otros con Ondiz Jones, Guillermo (2016): Corte Suprema 7 de septiembre de 2016 (acción de precario) en: www.poderjudicial.cl. 
Quijada Hernandez, Ingrid con Silva Rebolledo, María Elba (S) (2017): Corte Suprema 6 de julio de 2017 (acción de precario) en: www.poderjudicial.cl.

Ramos Avendaño, Dagoberto con Valencia Burgos Control Clima Limitada (2016): Corte de Apelaciones de Santiago 17 de mayo de 2016 (acción de precario) en: www.poderjudicial.cl.

Robles Cabrera, Julio con Terra Ramírez, Ricardo (2015): Corte Suprema 20 de noviembre de 2015 (acción de precario) en: www.poderjudicial.cl.

Rodríguez Contreras, Ricardo Antonio con Avendaño Herrera, Ramiro (2004): Corte Suprema 14 de diciembre de 2004 (acción de precario) en: www. poderjudicial.cl.

Rodríguez Valenzuela, Katherine con Valdebenito Silva, Luis Andrés (2014): Corte Suprema 4 de junio de 2014 (acción de precario) en: www.poderjudicial.cl.

Rojas Geldres, Iván con Jaramillo Soto, Sara (2017): Corte Suprema 20 de junio de 2017 (acción de precario) en: www.poderjudicial.cl.

Romero Nahuelpan, lucrecia con Montecinos Nahuelpan, Manuel (2008): Corte Suprema 24 de noviembre de 2008 (acción de precario) en: www.poderjudicial.cl.

Salvatierra Guajardo, Verónica con Lafuente lobos, Alex (2016): Corte de Apelaciones de Iquique 22 de febrero de 2016 (acción de precario) en: www.poderjudicial.cl.

Servicios Industriales Alegría Hermanos SPA con Ibarra Rodríguez, Aquiles Alonso (2015): Corte de Apelaciones de San Miguel 31 de julio de 2015 (acción de precario) en: www.poderjudicial.cl.

Sindicato Número 1 de Trabajadores de la Empresa Nestlé Chile S.A. y otros con Fábricas Tradicionales Federación de Sindicato (2016): Corte Suprema 22 de junio de 2016 (acción de precario) en: www.poderjudicial.cl.

Sociedad Inmob. y Asesoría Aida Ltda. con Cruz Arcas, Ximena Pamela (2017): Corte Suprema 29 de junio de 2017 (acción de precario) en: www.poderjudicial.cl.

Soto Bastías, héctor con Cuevas Martínez, María Olga (2015): Corte de Apelaciones de Concepción 4 de agosto de 2015 (acción de precario) en: www.poderjudicial.cl.

Valenzuela Muñoz, Ramón con Torrijos Avila, Ruth (2015): Corte de Apelaciones de Talca 30 de octubre de 2015 (acción de precario) en: www.poderjudicial. cl.

Vallejos Campos, Sonia y otra con Opazo Espinoza, Guillermo (2016): Corte Suprema 30 de mayo de 2016 (acción de precario) en: www.poderjudicial.cl. 
Vargas Vargas, Elba con Llano Fuentes, Juan (2016): Corte de Apelaciones de Santiago 26 de octubre de 2016 (acción de precario) en: www.poderjudicial.cl.

Veas Heredia, Nelly con Pizarro Ibáñez, Violeta (2012): Corte Suprema 4 de diciembre de 2012 (acción de comodato precario) en: www.poderjudicial.cl.

Vega Anjel, María con Arévalo Valenzuela, Joel y otra (2017): Corte Suprema 3 de enero de 2017 (acción de precario) en: www.poderjudicial.cl.

Vergara Díaz, Camilo con General Gutiérrez, Vicente (2016): Corte Suprema 17 de octubre de 2016 (acción de precario) en: www.poderjudicial.cl.

Vidal Vidal, Carlos con Oyarce, Pedro Tapia (2015): Corte Suprema 10 de diciembre de 2015 (acción de precario) en: www.poderjudicial.cl.

Villanueva Vásquez, Eliana Guacolda con Prats Larraín, Jorge Antonio (2002): Corte de Apelaciones de Santiago 22 de enero de 2002 (acción de precario) en: www.poderjudicial.cl.

Villegas Alvarado, Verónica Ester con Oliva Ferran Jorge Alfredo (o) (2017): Corte Suprema 29 de junio de 2017 (acción de precario) en: www.poderjudicial.cl. 